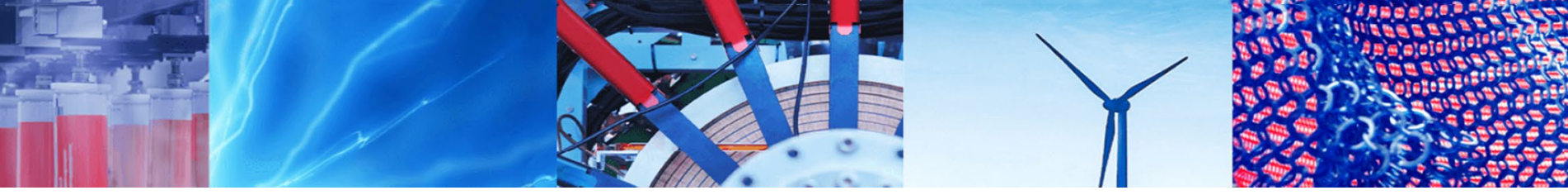

Review Paper

\title{
Large-scale triaxial and box testing on railroad ballast: a review
}

\author{
Yahia Alabbasi $^{1,2}$ (D) Mohammed Hussein ${ }^{1}$ \\ Received: 23 July 2019 / Accepted: 4 October 2019 / Published online: 11 November 2019 \\ (C) The Author(s) 2019 OPEN
}

\begin{abstract}
The use of railway transportation systems has been increased throughout the years. The conventional ballasted tracks have been used widely in many countries around the world. Ballast material is the basic element of ballasted tracks. Ballast degrades and deforms after service. Therefore, periodical ballast maintenance is needed which is a cost and time expensive activity. Understanding ballast mechanical behavior leads to better design and efficient maintenance. From the literature, experimental approach is used to understand the mechanical behavior of railroad ballast. Traditional experimental tests provide inaccurate results due to the large ballast particle size with relative to sample size. Researchers used large scale triaxial and box tests extensively to understand the mechanical behavior of railroad ballast. The target of this paper is to present a concise review of the extensive literature presented on the mechanical behavior of railroad ballast using large scale triaxial and box testing. It discusses the various aspects of large-scale equipment such as apparatus' set-up, size, material and shape, simulated load condition and test purpose. It presents the key findings of the large-scale triaxial and box tests in understanding ballast mechanical behavior.
\end{abstract}

Keywords Railroad ballast · Ballasted track $\cdot$ Large scale test $\cdot$ Triaxial test $\cdot$ Box test

\section{Introduction}

In many countries around the world, railways play a vital role as a mean of transportation. Railways have many advantages with relative to other means of transportation. Railways cover long distances in high speed, cheap, safe, efficient and environmentally friendly mean of transportation [1-3]. Moreover, railways are considered as a public welfare for many countries around the world [4].

$\mathrm{Li}$ et al. [5] divided the railway infrastructure into four main components (Fig. 1); track, structure, power, communication and train control. Railway track is considered as the basic element of railway infrastructure. Railway track is the supporting platform that transforms the trains' loads from track superstructure to track substructure. Trains run on different railway track systems; ballasted and ballastless (e.g. slab and embedded track) systems [6]. The ballasted tracks have the majority usage in the world due to their low cost, besides, the greater gained experience compared to new ballastless tracks [7]. Ballasted tracks have been used in the beginning of railways and ballastless tracks have been introduced in 1960s [8]. A ballasted track consists of two main structures: superstructure and substructure [9]. The main elements of the two structures of a typical ballasted track are shown in Fig. 2.

Generally, good knowledge of track superstructure is gained through research and experience throughout the years. However, the mechanical behavior of substructure's elements including ballast layer is not still fully understood with relative to superstructure components. The substantial role of ballast in railway track, besides, the needs of periodic and costly $[10,11]$ ballast maintenance raise the research interests on understanding the mechanical behaviour of railroad ballast for better design and efficient maintenance. From the literature, there are two

Yahia Alabbasi, ya1107037@qu.edu.qa|'Department of Civil and Architectural Engineering, Qatar University, P.O. Box 2713, Doha, Qatar. ${ }^{2}$ Qatar Transportation and Traffic Safety Center, Qatar University, Doha, Qatar. 


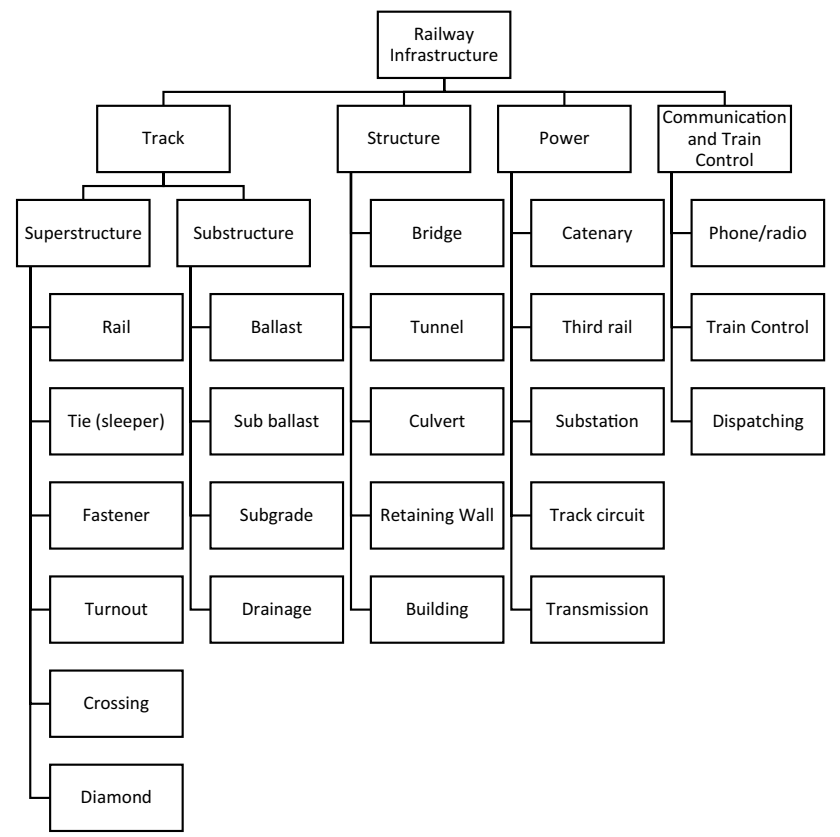

Fig. 1 Railway infrastructure's components reproduced from [5] main approaches used to understand ballast mechanical behaviour; experimental testing and modelling.

There are number of traditional experimental tests used to identify the mechanical and physical characteristics of granular material like conventional triaxial test, conventional direct shear test, petrographic analysis, crushing test and Los Angles abrasion test. Indraratna et al. [10] recommended avoiding the use of conventional tests for understanding the mechanical behaviour of granular material as they rottenly produce confusing results due to the large granular particles size relative to test sample size. McDowell et al. [12] showed the need of large scale equipment to experiment ballast strength. This raises the need of the large-scale experimental tests to be used in order to understand ballast mechanical behaviour. From the literature, there are various largescale tests were used to understand the mechanical behaviour of railroad ballast as given in Table 1. However, the large-scale triaxial and box tests, which represent the real field conditions, have been used intensively in typical ballast track [9]
Fig. 2 Cross section view of

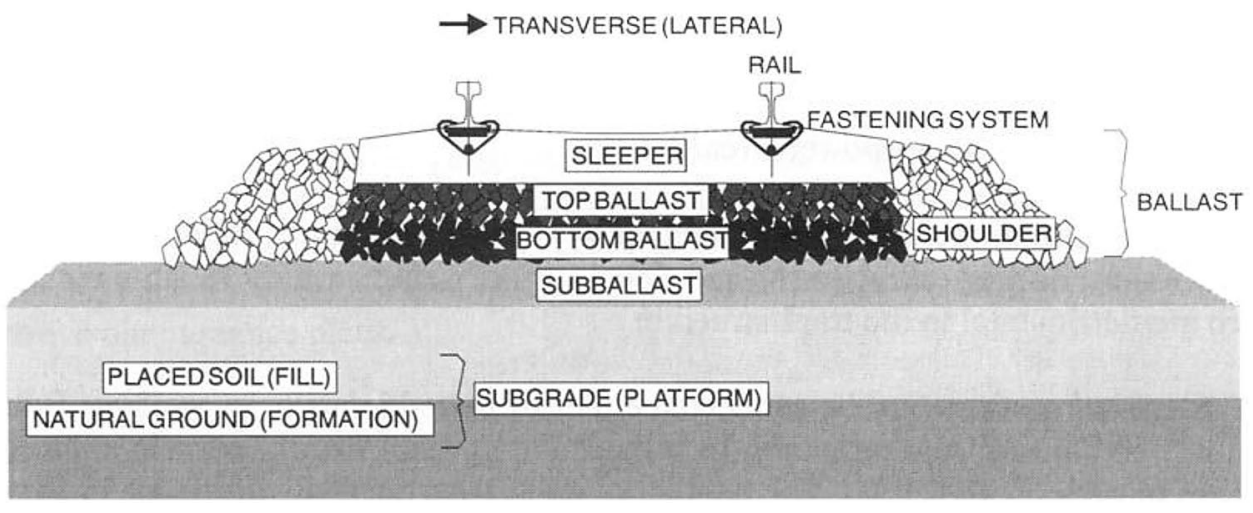

Table 1 Large scale tests that were used in the literature to understand the mechanical behavior of railroad ballast

\begin{tabular}{ll}
\hline Large scale experimental test & References \\
\hline Triaxial test & {$[10,17-23,25,27-29,31-39,47,64,65,76]$} \\
Box test & {$[9,89-100,102,104,106-108,112,113]$} \\
Plate test & {$[114]$} \\
Vibrating table test & {$[115]$} \\
Oedometer test & {$[12,91]$} \\
Pullout test & {$[103,116,117]$} \\
Direct shear test & {$[118-125]$} \\
Shaker test & {$[126]$} \\
Railway track facility & {$[21,37,103]$} \\
Full scale of ballasted track model & {$[21,37,102,103,127,128]$} \\
Half-track of ballasted track model & {$[129]$} \\
$1 / 3$ th scale of ballasted track model & {$[130]$} \\
$1 / 5$ th scale of ballasted track model & {$[131,132]$} \\
\hline
\end{tabular}


Fig. 3 Estimated number of publications from 1977 to 2019 related to large-scale triaxial and box experimental tests, obtained from the Scopus using the following keywords: Railroad ballast OR Ballast AND Large scale triaxial test OR Box test AND NOT Numerical AND Simulation
Number of Publications (1977-2019) 25

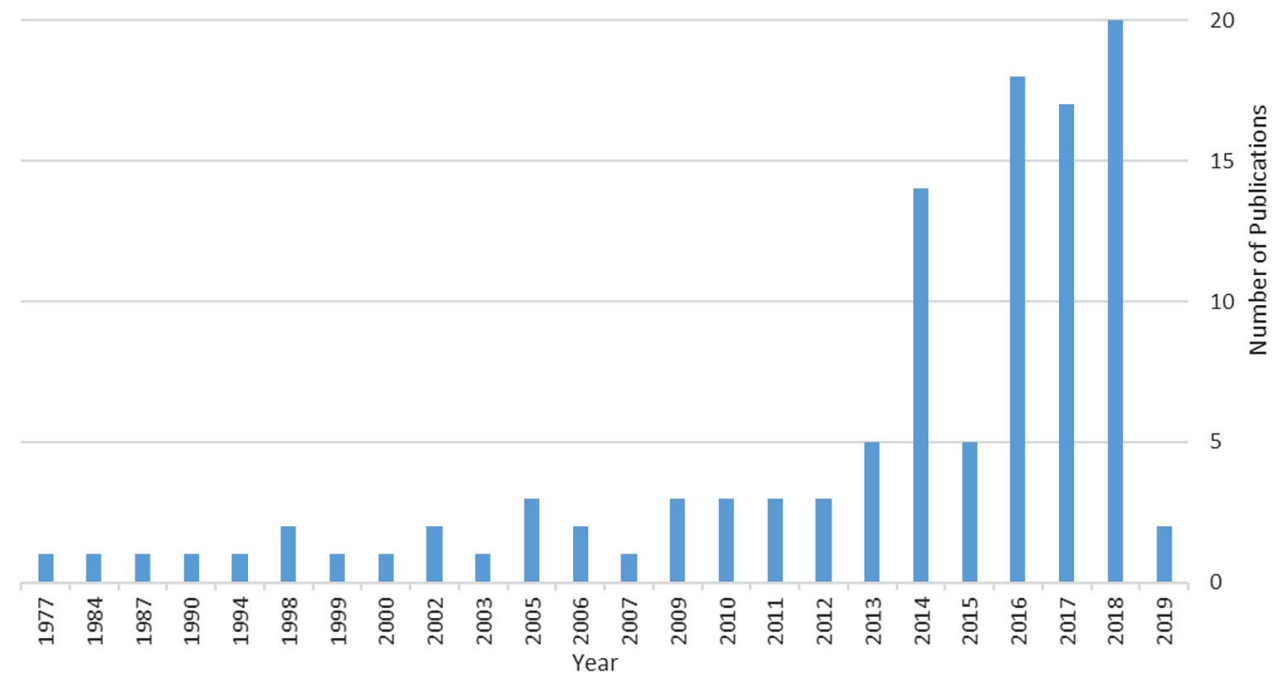

the literature to understand the mechanical behaviour of railroad ballast throughout the years as shown in Fig. 3 .

The aim of this paper is to summarize the main efforts and concerns in the literature on understanding ballast mechanical behaviour using large scale experimental testing and the necessity of further future research work.

The rest of this paper consists of four sections. The second and third sections reviews the literature on using large scale triaxial test and box test respectively in understanding ballast behavior. Finally, the conclusion section which summarizes the key points of the paper and the need for future work.

\section{Large-scale triaxial test}

Several studies from the literature used large-scale triaxial test to understand the mechanical behaviour of railroad ballast $[10,13-30]$. The main purpose of large-scale triaxial test is to get a rich understanding of the mechanical properties of railroad ballast material. For example, shear strength, angle of friction, shear stress-strain behaviour and volumetric change behavior. It was used also to study and understand the influence of different parameters (e.g. ballast martial type, ballast particle size distribution, inclusion of geotextiles and fouling degree) on ballast mechanical properties.

This section discusses the different concerns and main findings in the literature about large scale triaxial testing that is used to understand ballast mechanical behaviour.

\subsection{Test type}

There are three types of triaxial tests based on consolidation and drainage allowance; consolidated drained, consolidated undrained and unconsolidated undrained. The consolidated drained triaxial test is used for railroad ballast applications as it represents the real conditions.

There are two types of triaxial tests that were conducted in the literature based on the load application; monotonic and cyclic tests. In the monotonic test the vertical load is applied with a constant application rate (strain rate) in one direction (compression).

In the cyclic test the vertical load is applied in an oscillating manner. Cyclic test is more representative to the real scenario where train passage results a number of loading pulses on a track substructure due to the number of train axles.

Nevertheless, both types are used to understand the mechanical behavior of railroad ballast, besides, the influence of various variables on ballast mechanical behavior like particle size distribution, fouling degree, inclusion of geotextiles and initial ballast arrangement as discussed below in Sect. 2.7.

From the literature, several studies on railroad ballast was done using monotonic triaxial test [10, 29, 31-33]. Large number of publications in the literature studied the mechanical behaviour of railroad ballast under cyclic loading condition like $[18,22,23,25,27,34,35]$. Other studies investigated the mechanical behavior of railroad ballast under monotonic and cyclic loading conditions such as [17, 19-21, 28, 36-39]. In general, Monotonic triaxial test 
is used mainly to understand the short-term behavior of railroad ballast. Cyclic triaxial test is commonly used to understand the long-term behavior including permeant deformation of railroad ballast.

\subsection{Large scale equipment}

As ballast particles are large in size, traditional triaxial test equipment is not sufficient to be used in testing railroad ballast as it may produces inaccurate results [10]. Large scale triaxial apparatus is needed to understand the mechanical behaviour of railroad ballast experimentally.

There are number of large-scale triaxle tests designed and used to study the mechanical behaviour of railroad ballast. For example, large scale triaxle equipment at University of Wollongong designed by Indraratna et al. [10] and Indraratna [40] which was used later for other studies related to railroad ballast $[18,24,25,27,29]$, at the University of Illinois by Mishra et al. [23], at the Missouri Institute of Science and Technology by Sevi et al. [20], at Norwegian University of Science and Technology by Skoglund et al. [41] which was used later by Nålsund et al. [22] and TAJ2000 (Tianshui Hongshan Testing Machine) used by Bian et al. [28].

\subsection{Sample size}

Large scale triaxial tests samples have different sizes compared to traditional triaxial test specimens. From the literature, researchers used different sample sizes to be used in triaxial testing of railroad ballast as summarized in Table 2 .

The size of the sample in the large-scale triaxial test should be representative to obtain accurate results and reduce the effects of sample size, especially that ballast aggregates have large particle size in the range of 10-50 $\mathrm{mm}$ [42]. There are two approaches used in the literature to identify the sample size of the large-scale triaxial test.

Table 2 Sample size of triaxial tests used in the literature to understand railroad ballast behaviour

\begin{tabular}{ll}
\hline Sample size $(\mathrm{mm})$ & References \\
\hline 419 dia $\times 864$ height & {$[20]$} \\
305 dia $\times 610$ height & {$[23,31,33,35,39]$} \\
300 dia $\times 600$ height & {$[10,18,22,25,27-29$,} \\
& $32,34,38,64,65$, \\
300 dia $\times 450$ height & $76]$ \\
254 dia $\times 645$ height & {$[21,37]$} \\
236 dia $\times 455$ height & {$[17,36]$} \\
245 dia $\times 508$ height & {$[19]$} \\
\hline
\end{tabular}

The first one is the " $D / d_{\max }$ " ratio. Where " $D$ " is the triaxial test's specimen diameter and " $\mathrm{d}_{\max }$ " is the maximum particle diameter. From the literature, researchers used different values of " $D / d_{\max }$ " ratio to determine the sample size used for large scale triaxial testing of railroad ballast. For instance, 4.7 [19, 43], 4.8 [44], 5.7 [45], 6 [37], 7 [17] and 8 [20]. Skoglund [15] recommended that representative sample size should have " $D / d_{\max }$ " ratio in the range of 5-7. Fair [30] presented in his literature review that the " $\mathrm{D} / \mathrm{d}_{\max }$ " ratio differed from 4.7 to 10 . Marachi et al. [46] and Indraratna et al. [45] recommended a value of 6 by which the sample size effects are marginal and negligible. Aursudkij [37] determined the sample size based on a " $D$ / $\mathrm{d}_{\max }$ " ratio equals to 6 .

The second one is the " $\mathrm{H} / \mathrm{D}$ " ratio. Where " $\mathrm{H}$ " is the triaxial test's specimen height. A number of researchers $[10,18$, $22,23,25,31,33-35,38,39,47]$ in the literature designed their large-scale triaxle sample to have a corresponding aspect ratio of " $\mathrm{H} / \mathrm{D}$ " equal to 2 . Other researchers used a sample size with a "H/D" ratio of 1.5 [21, 37], 1.93 [19], $2.06[20]$ and $2.54[17,36]$ in their studies. Bishop and Green [48] recommended that H/D ratio should be 2 to minimized the friction effects at sample ends which may cause an inaccurate results. End friction influences the friction angle of the sample [49].

\subsection{Sample compaction}

Sample compaction is one of the key aspects in sample preparation prior to testing. In the field, ballast layer undergoes a compaction process to reduce ballast initial settlement before traffic operations. This is done by different methods like natural stabilization (number of train passes at a slower speed of traffic trains), dynamic stabilization (application of vertical load with lateral vibration of rails using specialized equipment) or crib compaction (vertical vibration of compactor plates placed at crib and shoulder of ballast with application of vertical load using specialized equipment) for new ballast [50]. For old ballast, compaction is done during ballast maintenance by tamping or stone blowing processes using vibratory tines.

In large-scale triaxial test, ballast sample is compacted by different approaches. From the literature, most of the researchers compacted the ballast sample in different number of layers.

Shenton [13] compacted his sample in four layers using tamping tines. His compaction method was not recommended by Kolisoja [51] as it is dependable on the tamping equipment and it may introduce some particle crushing in the sample. Indraratna et al. [10] compacted their ballast sample manually using a standard Proctor hammer. Each layer $(50-60 \mathrm{~mm}$ ) is exposed to 25 blows. The authors used a $4 \mathrm{~mm}$ thick rubber mad to reduce the 
corners breakage during the compaction process. Suiker et al. [17] used steel rod to compact the equally thick eight layers of their ballast sample. Each layer is exposed to 40 blows. Mishra et al. [23], Qian et al. [39, 52] used electric jackhammer to copmact ballast sample layers. The authors applied four lifts to ballast sample with $4 \mathrm{~s}$ of compaction time for each lift. Skoglund [15], Nålsund [22] and Indraratna et al. [24, 32] used a vibrating plate compactor to compact each layer of their ballast samples. Kashani et al. [47] compacted ballast sample of eight layers using steel rod and manual tamper.

Key [16] and Anderson et al. [53] did not recommend the compaction of layers approach as it may be responsible for the uncommon orientation and leveling of ballast aggregates. The authors introduced a new approach to compact the ballast sample using a vibrating table which was later used by Anderson and Fair [19], Sevi et al. [20], and Aursudkij et al. [21]. It would be worthful to investigate the effect of the compaction methods on the behaviour of railroad ballast through large scale triaxial testing.

\subsection{Loading condition}

This section discusses the various parameters of loading condition used in large-scale triaxial testing of railroad ballast. For instance, strain rate (monotonic triaxial test), confining pressure, applied axial stress and frequency of applied cyclic stress (cyclic triaxial test). The effect of these parameters on the mechanical behavior of railroad ballast is discussed in Sect. 2.7.

\subsubsection{Strain rate}

For large-scale monotonic triaxial test, there are different values of strain rates used in the literature. The typical strain rate used in the consolidated drained triaxial test for soil mechanics and geoengineering applications is $0.0167 \%$ strain/second [52]. The consolidated drained triaxial test is used for railroad ballast applications as it represents the real conditions. The low used value of strain rate allows the excess pore pressure results from monotonic loading to dissipate.

From the literature, Qian et al. [39, 52] used a value of strain rate of $0.0167 \%$ strain/second in their large-scale triaxial testing of railroad ballast. However, there are number of publications in the literature used a strain rate quite close to the common value based on the equipment limitation like $0.0197 \%$ [20], 0.0117\% [10] and 0.00833\% [32] strain/second. Other researchers used very low strain rate either due to equipment limitation like $0.00367 \%$ strain/ second $[19,21,37]$ or to allow for full drained condition of clay fouled ballast like $0.00153 \%$ strain/second [29]. Number of researchers $[31,33,52]$ used a higher strain rate equals to $5 \%$ strain/second to represent the high loading rate from trains. The high strain rate approach is introduced by Garg and Thompson [54] to simulate the high loading rate form trains.

The strain rate value dose not influence the stress-strain curve of railroad ballast under triaxial testing; however, it is recommended to use low strain rate in large-scale triaxial testing of railroad ballast for safety concerns and better laboratory control [52]. The better laboratory control ensures the repetition and reproduction of test results [55].

\subsubsection{Confining pressure}

In the field, ballast layer is self-confined under certain pressure at a range of 5-40 $\mathrm{kPa}$ as reported by Selig and AlvaHurtado [56]. Indraratna et al. [57] reported that ballast confining pressure is infrequently exceeds $60 \mathrm{kPa}$; it is in the range of $10-40 \mathrm{kPa}$ is for a trains with an axle load of 20-30 t; and equals to $60 \mathrm{kPa}$ and less for a trains with an axle load of $40 \mathrm{t}$ and more.

From the literature, number of publications used a confining pressure values in the range $5-60 \mathrm{kPa}$ in large-scale triaxial testing of railroad ballast like [20-23, 25, 27, 29, $35,39]$. However, some researchers in the literature used higher values of confining pressure ( $>60 \mathrm{kPa})$ which is not the real condition at the real track [10]; to investigate and do a parametric study about the effect of confinement on railroad ballast mechanical behaviour using large-scale triaxial [10, 18, 19, 31-34, 38]; the effect of ballast confinement on the mechanical behaviour of railroad ballast is discussed in Sect. 2.7.

Key [16] used variations of deviator stresses in his triaxle test, between $12.5 \mathrm{kPa}$ and $250 \mathrm{kPa}$. Suiker et al. [17] used two different confining pressures of 41.3 and $68.9 \mathrm{kPa}$ in their study. Indraratna et al. $[18,34]$ used a broad range of confining pressure from 1 to $240 \mathrm{kPa}$ in their triaxial tests to investigate the effect of confining pressure on ballast behaviour.

Usually, the sample confinement in traditional triaxial test is done either using thick rubber membrane or pressurized fluid control system. However, Indraratna et al. [10] and Key [16] recommended to apply a confining pressure instead of using a thick rubber membrane to confine the railroad ballast sample in large scale triaxial test; as the thick rubber membrane provides a marginal confinement to railroad ballast sample compared to confining pressure. The use of pressurized fluid control system is not recommended to be used in large scale triaxial test; as it makes the equipment heavy to require mechanical support [20].

From the literature, there are different approaches used to apply the required confining pressure in large-scale triaxial testing. Number of researchers [17, 22, 23, 31] used air pressure control system to apply a confinement to 
the sample via air pressure valve. Aursudkij et al. [21,37] used air and water control system to confine the ballast sample; where the pressurized air is used to compress the outer cell that consequences the water in the inner cell to pressurized and results a confinement on the ballast sample as shown in Fig. 4. The same approach was used by Trinh et al. [38] to confine ballast sample in a large scale triaxial test developed by Dupla et al. [58]. However, the use of fluid material for the confinement purposes in large-scale triaxial test is not recommended by Sevi et al. [20]; as it makes the assembly heavy and hard to handle in case of mechanical support requirements. This led Sevi et al. [20] to introduce a new alternative to be used for railroad ballast sample confinement in large-scale triaxial test. The used a backpressure to vacuum and confine the sample (vacuum confinement). This done by having two ports at the top cap to control and measure the vacuum as shown in Fig. 5. The volumetric change for either air or air and water control systems is measured by measuring the inflow and outflow volumes; however, vacuum confinement has limitations in measuring the volumetric change of the sample. Nevertheless, Sevi et al. [20] introduced two methods to measure the volumetric change of vacuum confined sample using radial strain transducers inside the sample and digital image analysis (Fig. 6).

\subsubsection{Applied axial stress}

The substructure of the railway track is exposed to different types of loads. Selig and Waters [9] classified the

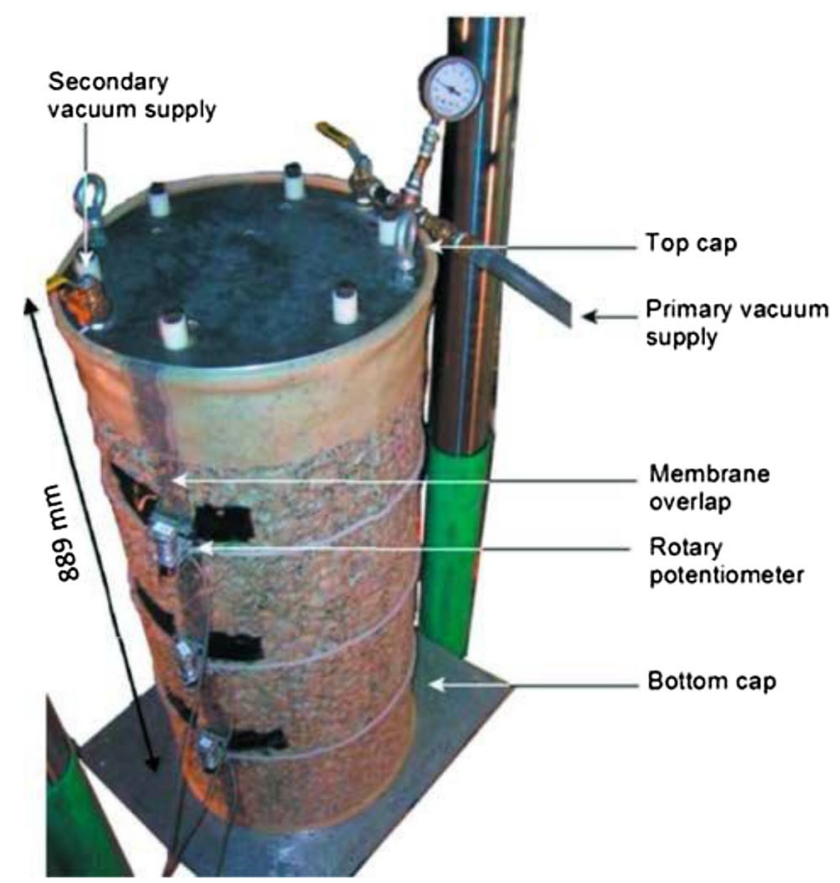

Fig. 5 Details of top and bottom caps used in large scale triaxial instrument by Sevi et al. [20]

loads exposed to ballast layer into two main types; vertical and squeezing loads (from tamping process). There are other minor loads like lateral and longitudinal forces; however, it is difficult to estimate the minor loads. The vertical loads are static, cyclic (quasi-static) and impact loads
Fig. 4 Schematic drawing of large-scale triaxial equipment $[21,37]$

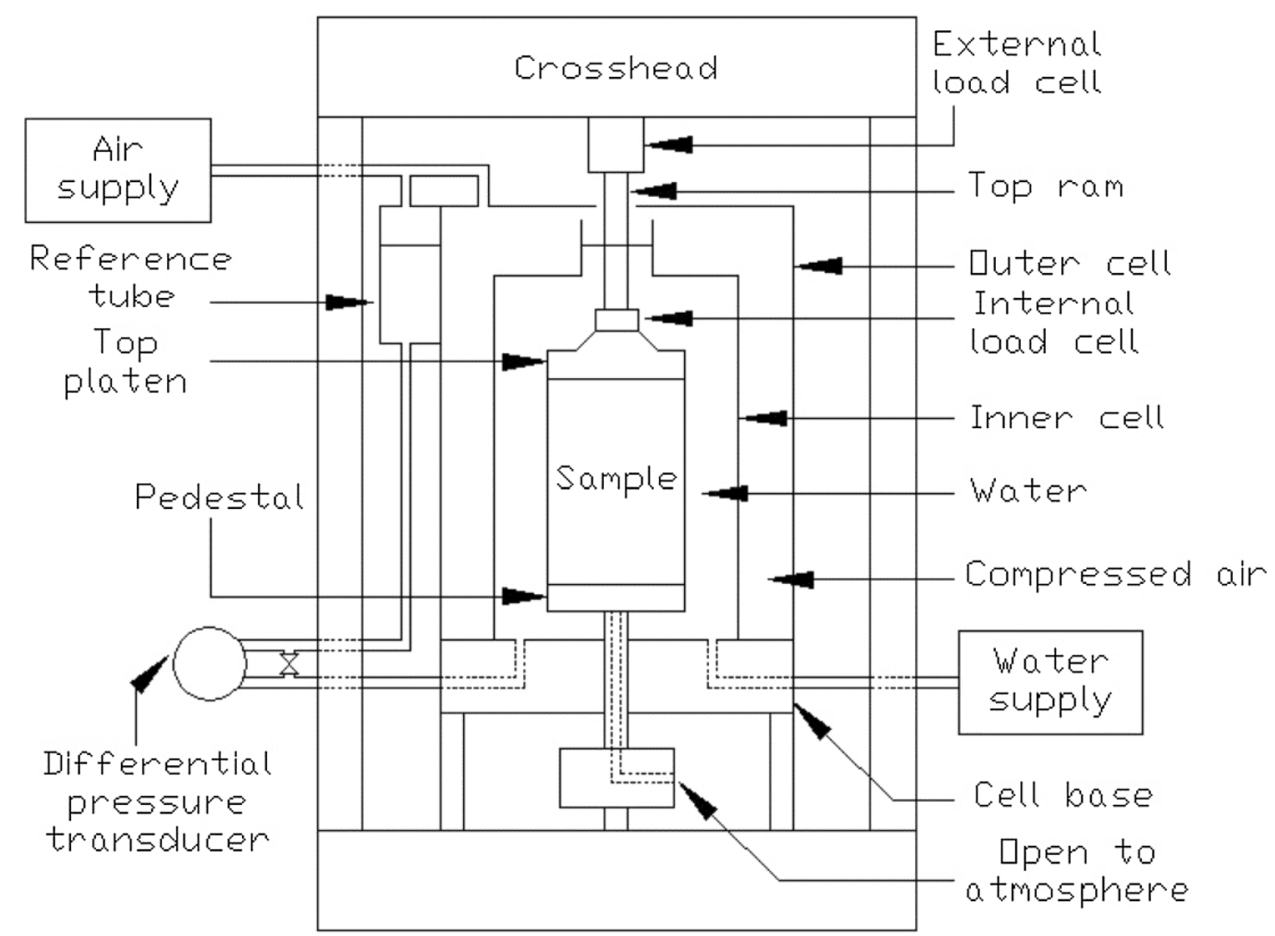


Fig. 6 Large scale triaxial testing instrument with the usage of digital imaging built at the Missouri University of Science and Technology [20]

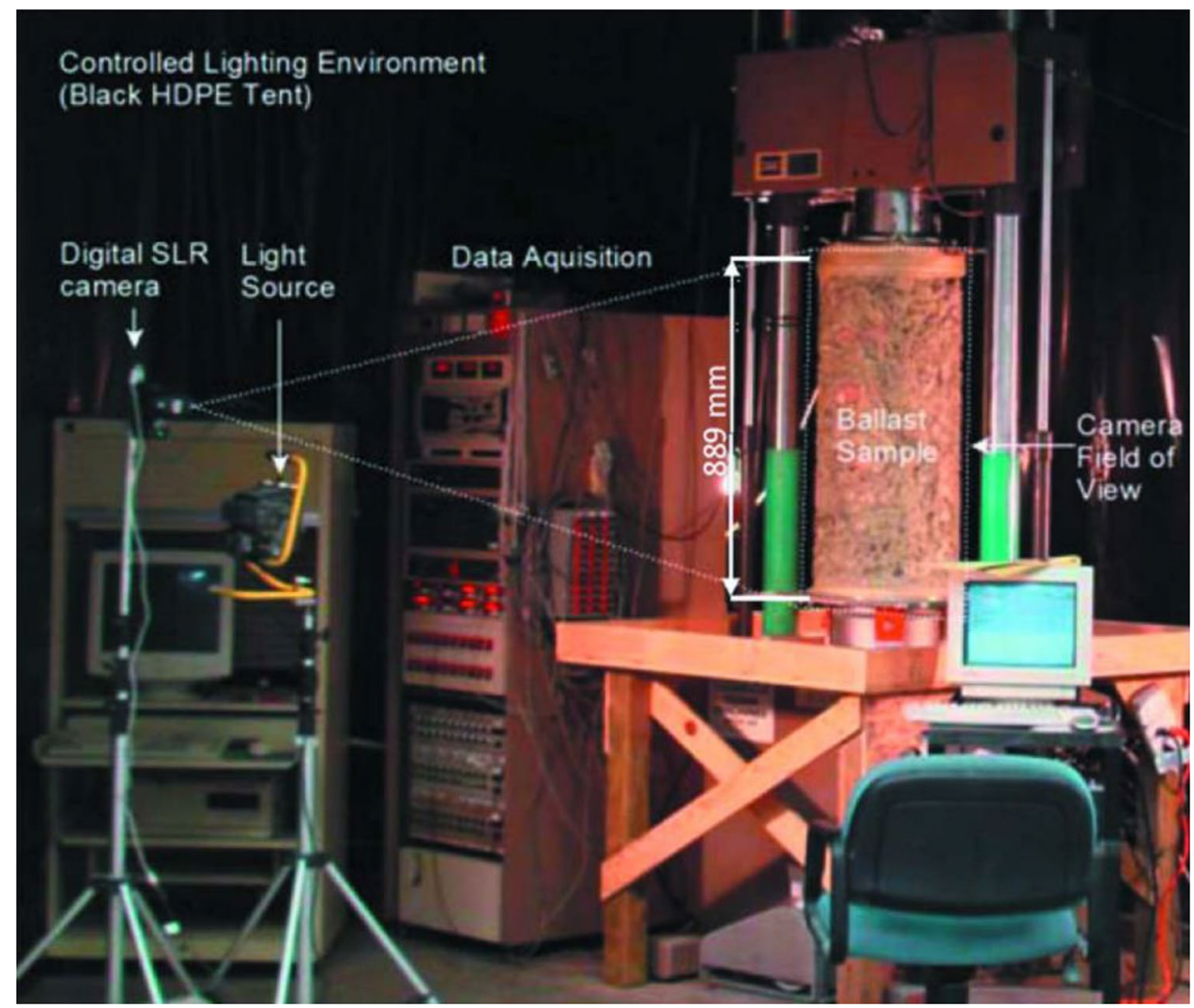

(dynamic). Static loads are dead and live loads. Dead load is the weight of railway track and live load is the weight of a non-moving train which is commonly expressed in terms of axle load. Static live load from train weight is more considerable than static dead load. Dead load is considerable in analyzing and designing certain topics like slope stability of track built on high embankment and subgrade issues at a large ballast layer [5].

Li et al. [8] described the typical static dead load ranges for each track component; rails weighted from about $45 \mathrm{~kg} / \mathrm{m}$ to $75 \mathrm{~kg} / \mathrm{m}$, timber tie weighted about $110 \mathrm{~kg}$ and concrete tie weighted $360 \mathrm{~kg}$. They described the typical track substructure density for ballast $\left(1760 \mathrm{~kg} / \mathrm{m}^{3}\right)$, sub ballast $\left(1920 \mathrm{~kg} / \mathrm{m}^{3}\right)$ and subgrade $\left(2240 \mathrm{~kg} / \mathrm{m}^{3}\right)$. With regards to static live load, Fryba [38] presented statistical measurements of train operations in Czech Republic. The author summarized that there are three major axle load ranges; $180-200 \mathrm{kN}$ for fully loaded freight cars and locomotives, about $100 \mathrm{kN}$ for the passenger cars and partially loaded freight cars and about $50 \mathrm{kN}$ for empty freight cars.

A ballasted railway track is also exposed to cyclic loading due to the train repetitive passages. A train consists of a number of train cars. Each train car has typically four axles with different spacings. Each axle exerts a load on ballast layer. For one train passage, the train applies a number of vertical loadings on the ballast layer. This generates a number of loading pulses. Cyclic loading could be also classified as quasi static loading for a frequency range of $0-20 \mathrm{~Hz}[59,60]$. Remennikov and Kaewunruen [61] defined the quasi-static loading as an applied vertical loading with slow application rate. Under static and quasi-static loadings track response is governed by its stiffness only. Inertial forces are introduced but they can be neglected as they are small due to the slow rate of load application. Stiffness forces are based on the track material properties. Inertial forces are based on the mass and acceleration of track elements under loading. The quasi-static loads typically are around 1.4-1.6 times the static wheel load without the effects of unbalanced super elevation [62]. There are other minor quasi-static loads usually introduced to the railway track like centrifugal force, gross tare and cross winds [7]. For higher cyclic loading frequency $(>20 \mathrm{~Hz}$ ) dynamic effects are introduced where the system is governed by its stiffness and inertial forces.

Furthermore, track substructure is exposed to impact loads due to rack and vehicle irregularities. For example, irregular track stiffness, rail corrugations, rail discontinuities (welds, joints and switches), wheel burns and wheel flats [7]. Impact loads are considered as dynamic loading. Remennikov and Kaewunruen [61] defined the dynamic loading as a time dependent loading; where the application rate of the dynamic load and between consecutive pulses is very small as well as the load magnitude changes 


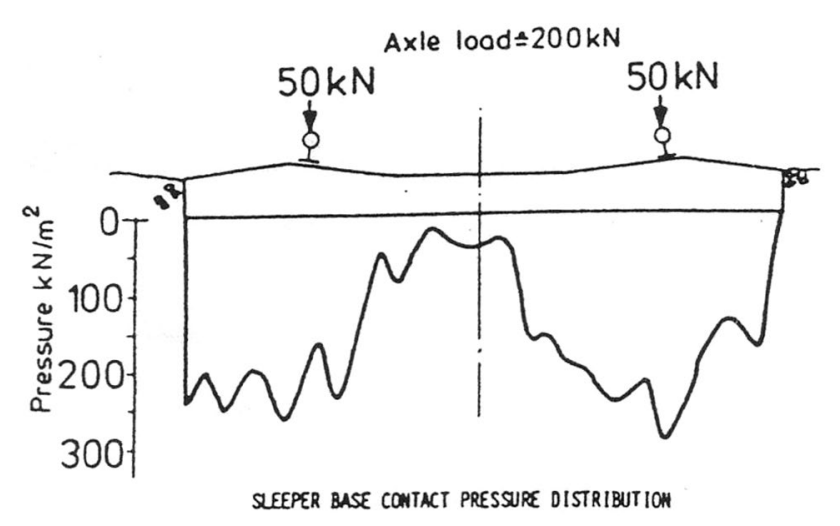

Fig. 7 Vertical stress at the sleeper base contact [13]

rapidly in a short period. Lee [63] pointed out that impact loading exerted on railway tracks are applied within very short periods of $2-10 \mu$ s where dynamic effect is maximum. Remennikov and Kaewunruen [61] estimated the dynamic loading due to the generated high frequencies to be about 1.5 times the static wheel load. Under dynamic loading the track response is governed by both stiffness and inertial forces, where the forces are applied in a short period of time. The track responses are governed by both stiffness and inertial forces. Inertial forces are considered as additional forces applied on the track and may cause serious failure to the railway track [62].

In 1978, Shenton [13] found that the vertical stress at the ballast sleeper interface was between 200 and $250 \mathrm{kPa}$ for an axle load of a passenger train equals to $100 \mathrm{kN}$ as shown in Fig. 7. Raymond and Buthurst [14] showed an agreement to Shenton [13]. Lackenby et al. [18] highlighted that most of the triaxial testing on railroad ballast used a value of axial stress below $750 \mathrm{kPa}$ to represents the typical stress on ballast layer.

Form the literature, most of the experimental research works on railroad ballast using large scale triaxial test used axial stress in this range of 200-250 kPa like [19, 22, 25, 27, 28 ] to represent the typical stress on ballast layer from a passenger train. Other researchers, used a high value of axial stress to represent a freight train like 1000 and $1250 \mathrm{kPa}$ [18].

Number of the studies in the literature related to largescale triaxial testing of railroad ballast used an axial stress as pure continuous sinusoidal [17-22, 25, 27, 28, 34, 36-38, $64,65]$ or haversine $[23,35,39,66]$ loading to represent train loading. The actual train loading is not a pure continuous sinusoid or haversine. Although, Li [67] recommended that haversine can represents one single axle loading only, number of loading axles cannot be represented by haversine. Train consists of number of cars. Each car has number of axles with different spacing. Each axle applies a vertical stress on track substructure. For better and accurate understanding of ballast behaviour using large scale triaxial test, it is recommended to use a more realistic loading application that represents train loading including the impact loads (dynamic effects) generated from track/vehicle irregularities.

\subsubsection{Frequency of applied cyclic stress}

The usual cyclic loading frequency for normal train is in the range of $8-10 \mathrm{~Hz}$, assuming an axle spacing of $2.6 \mathrm{~m}$ and a train speed of 75-94 km/h [21,37]; and for high speed train it may extent to $30 \mathrm{~Hz}[21,37]$. From the literature there are different ranges of the used frequencies in the cyclic large-scale triaxial tests based on the simulated train speed and axle spacing, besides, the equipment restraint and capacity.

As discussed above, sinusoid loading is the most used type of loading in the literature to represent the traffic repeated loading. The frequency of the sinusoidal cyclic loading is calculated by dividing the simulated train speed by the axle spacing.

From the literature, there are number of publications used low frequency values to represent low train speed like $0.5 \mathrm{~Hz}$ [19], $1 \mathrm{~Hz}[20,23,28,35], 4 \mathrm{~Hz}[21,37]$ and $5 \mathrm{~Hz}$ [22, 38]. Key [16] and Shenton [13] used small frequencies of $0.16 \mathrm{~Hz}$ and $0.1 \mathrm{~Hz}$ respectively to reduce the initial deformation of ballast.

Other studies used high values of loading frequency to represent high speed trains like $11 \mathrm{~Hz}$ [43], $20 \mathrm{~Hz}$ [18, 34] and $20-30 \mathrm{~Hz}$ [27]. There are a number of studies used broad range of loading frequencies in large-scale triaxial testing like $10-40 \mathrm{~Hz}$ [57] and 5-60 Hz [26] to study the influence of loading frequency on the mechanical behavior of railroad ballast via large scale triaxial test as discussed in Sect. 2.7.

\subsection{Ballast material}

Ballast aggregates are a result of crushed rocks. It is important to know the type of the ballast parent rocks as it affects ballast strength related properties like particle size, shape, cleavage fracture, porosity and angularity [68]. Moreover, ballast parent rock characteristics influence the mechanical behaviour of railroad ballast under real traffic loadings $[69,70]$. Ballast parent rock can be estimated by petrographic analysis. Petrographic analysis is an evaluation of the source, composition and nature of the handsample material under microscopic vision of thin sections of the specimen by an expert petrographer. Raymond [71] considered petrographic analysis as an important test in selecting ballast material and he concluded that 


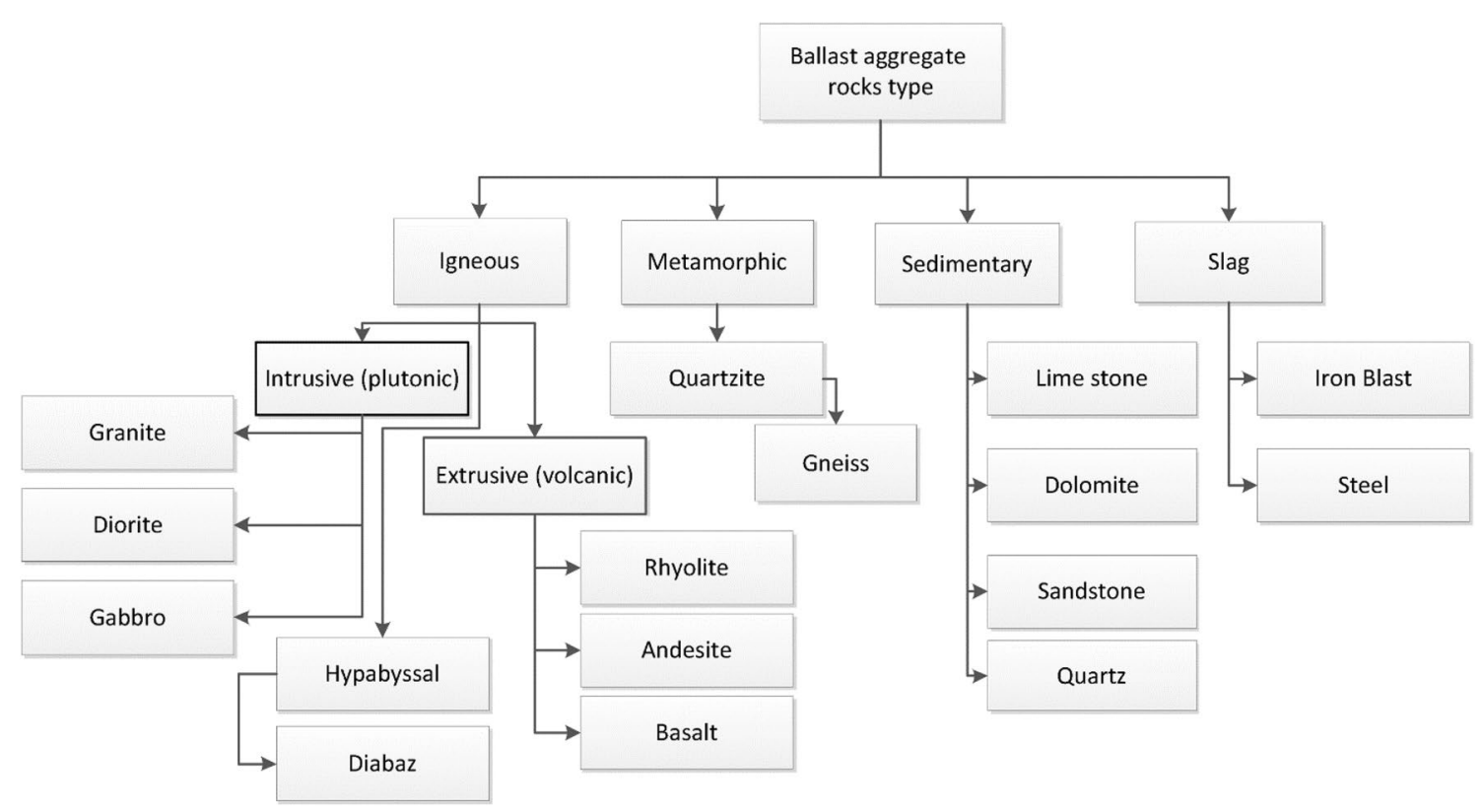

Fig. 8 Railroad ballast parent rock classification by Sadeghi et al. [68]

petrographic analysis can be a valuable estimation to the shape and porousness of railroad ballast.

Sadeghi et al. [68] classified the parent rock of ballast aggregates into four classifications as shown in Fig. 8. Extrusive igneous rocks (rheolite, andesite and basalt) are the most sufficient parent rocks for railroad ballast. Followed by metamorphic then sedimentary rocks and finally slag as the weakest rock to be chosen for railroad ballast. Indraratna [72] stated that the main parent rocks that are used to derive railroad ballast are igneous or metamorphic rocks and this why ballast morphology usually consists of rheolite, dolomite, basalt, gneiss, quartzite and granite minerals.

From the literature, there are various types of ballast material used in the triaxial testing of railroad ballast. For example, latite basalt $[10,17,18,25,27,29,32,34$, $36,64,65]$, granite $[19,47]$, granite and limestone $[21$, $37]$ and limestone $[23,31,33,35,39]$.

Nevertheless, there is low effort in the literature done about investigating the influence of ballast material type on the mechanical behavior of railroad ballast via large-scale triaxial testing. A comparative study is required to understand the influence of ballast material type on the shear strength, volumetric change and strain change of railroad ballast through large-scale triaxial test, besides, the recommendation for better material type to be used and selected in ballasted tracks. This has the potential to improve the performance railroad ballast and reduce the financial requirements associated with maintenance operation.

\subsection{Main findings of understanding ballast behaviour using large-scale triaxial test}

From the literature, large scale triaxial tests have been used to understand the characteristics of railroad ballast under triaxial loading condition like shear strength, friction angle, stress-strain behaviour and volumetric change under triaxial loading conditions. Moreover, they have been used to investigate the influence of other parameters like ballast particle size, confining pressure, cyclic loading frequency, ballast fouling and use of geotextiles on ballast mechanical behaviour.

Ballast aggregates are narrow graded, large, angular, free of dust and dirt, not disposed to cementing action and derived from crushed hard rock material [73]. The Particle Size Distribution (PSD) of railroad ballast has a significance influence on ballast performance under real track conditions. Ballast strength, deformation resistance and drainage properties are dependent on ballast PSD.

Ballast aggregate size gradations are commonly narrow not broad. Broad graded ballast aggregates layer provides shear strength and resistance to deformation with relative to narrow graded ballast aggregates layer; because of the low void ratio and the dense arrangement of particles $[74,75]$. As observed by Indraratna et al. [10] that broad 
gradation enhanced the shear strength of railroad ballast due to the small particles interlocking; through their experimental work using large-scale triaxial test under monotonic loading condition. The authors used two particle size distributions for comparison purpose; the upper and lower limit of Australian standards (T.S. $3402-83$, 1983) with coefficient of uniformity equals to 1.5 and 1.6 respectively.

There are number of studies in the literature that investigate the effect of PSD on the permanent deformation of railroad ballast. Nålsund [22] concluded that broad gradation results in a lower axial permeant deformation and particle breakage. His conclusion was derived by comparing the results from large-scale triaxial test under cyclic loading condition between two different gradations; the Norwegian railway ballast standards (EN13450, Category E) considered as narrow gradation and the AREMA No. 4 considered as broad gradation.

Nevertheless, broad gradation provides low capacity for fouling material to be stored and low drainage features to the track [10] as well as challenges in material handling and delivering due to the high chance of segregation during construction. But narrow graded ballast aggregates layer provides good void capacity for fouling storage, good drainage capability of the track and easy handling during construction as it is not exposed to segregation.

Selig [42] suggested that the perfect ballast particle sizes are in the range of $10-50 \mathrm{~mm}$ with some aggregates outside this range. However, there is no specific ballast gradation to be used everywhere, as each railway association has its own ballast gradation specification. However, the most general used and recommended PSD of railroad ballast with a particle size range almost of $10-60 \mathrm{~mm}$. Indraratna et al. [27] introduced a new particle size distribution that showed a lower ballast degradation and deformation under high loading frequencies (20 and $30 \mathrm{~Hz}$ ); based on large-scale triaxial testing under cyclic loading condition. Their proposed particle size distribution had the following parameters: $1.8 \leq$ coefficient of uniformity $\leq 2.0$, $\lambda=3.0-4.4$ and $E=0.375-0.376$; where $\lambda$ is dimensionless particle size distribution parameter and is and $E$ is ellipsoidness ratio. The authors classified the particle breakage of railroad ballast under cyclic loading based on coefficient of uniformity into two zones; high breakage and reduced breakage zones. The authors observed that particle breakage of railroad ballast can be reduced by using PSD that has a corresponding $\mathrm{Cu}$ value of 1.8 and more. Sun and Nimbalkar [76] observed through large scale triaxial testing that particle breakage is influenced by relative density of ballast in addition to PSD. The authors observed that the higher ballast density the less particle breakage is occurred for the same initial PSD of the samples.
In 2017, Sun et al. [65] investigated the effect of PSD on the permanent deformation of railroad ballast for different PSDs. The authors suggested an optimal PSD for railroad ballast using fuzzy mathematical analysis to accommodate the increase of track speed and minimize particle breakage with a median particle size of 36-41 mm, maximum particle size of $53 \mathrm{~mm}$ and Cu value close to 2 . Similar PSD by Ref. [77] was also found with $\mathrm{Cu}=1.9$.

There is a considered effort in the literature to study the influence of particle size distribution from different railway associations' standards through numerical discrete element method [78-80]. However, there is a low effort in the literature about studying the influence of different particle size distributions by railway associations on the machinal behavior of railroad ballast through large-scale triaxial test. This has the potential to select and recommend the proper particle size distribution for railroad ballast to be used worldwide instead of having a number of different particle size distributions based on different standards from various railway associations.

Confining pressure is considered as one of the main parameters that influence the mechanical behavior of railroad ballast; however, it is usually underestimated in ballast track design and construction. This is because, there is no design criteria highlights the importance of ballast confining pressure [18]. Nevertheless, researchers used large-scale triaxial test to understand and investigate the influence of ballast confining pressure on its mechanical behavior.

In 1998, Indraratna et al. [10] studied the effect of confining pressure on friction angle of railroad ballast under monotonic loading through large scale triaxial test. The authors observed that as confining pressure increases, ballast friction angle decreases. The same observation was observed for other rockfill material by Indraratna et al. [45], Marsal [81, 82], and Charles and Watts [83]. Indraratna et al. [10] found that after $400 \mathrm{kPa}$ of confining pressure, the influence of confining pressure on friction angle was marginal.

Indraratna et al. [34] studied the influence of confining pressure on the particle breakage (degradation) of ballast under cyclic loading. The authors divided the particle breakage of ballast into three zones based on effective confining pressure $\left(\sigma_{3}\right)$ : Dilatant Unstable Degradation Zone (DUDZ) at $\sigma_{3}<30 \mathrm{kPa}$, Optimum Degradation Zone (ODZ) at $30 \mathrm{kPa}<\sigma_{3}<75 \mathrm{kPa}$, Compressive Stable Degradation Zone (CSDZ) at $\sigma_{3}>75 \mathrm{kPa}$. It was observed that at low confining pressure ballast breakage is marginal as contact between particles are minimum. However, as the confining pressure increases the more ballast layer is compressive and ballast breakage increases as contact between ballast particles is maximum. 


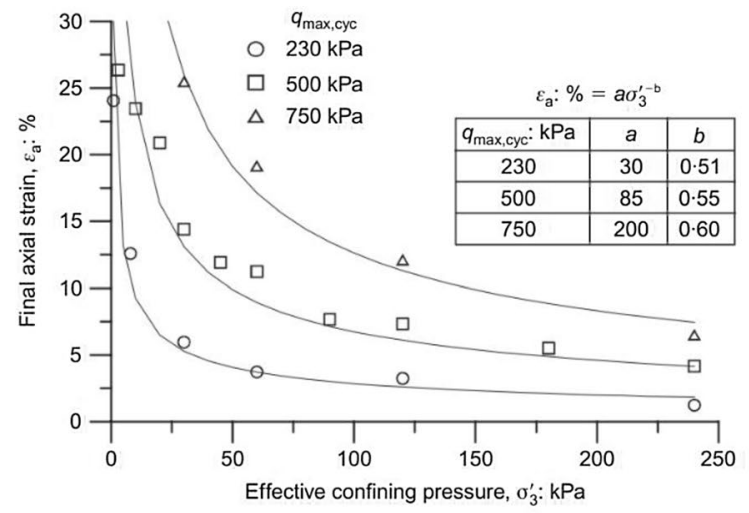

(a)

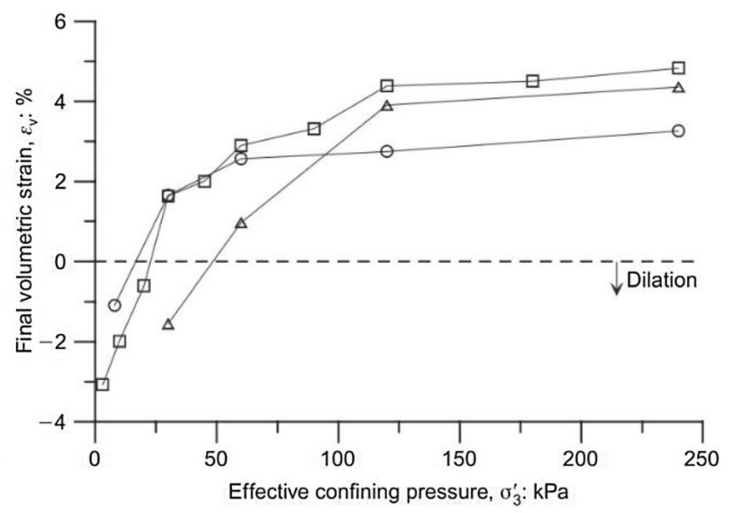

(b)

Fig. 9 Effect of confining pressure on a axial strain and $\mathbf{b}$ volumetric change of railroad ballast at the 500,000 cycle [18]

Lackenby et al. [18] found that the degradation zones are also dependent on the maximum deviator stress. The authors recommended that DUDZ should be avoided for ballast track due to the high resulted permanent deformation. The authors found that ballast corner breakage occurred mostly under low confining pressures while splitting breakage occurred mostly under high confining pressures. However, ballast breakage is reduced by using an optimized confining pressure (ODZ). The authors found that as confining pressure increases, axial strain of ballast decreases (Fig. 9a). Ballast layer dilatancy which is unpreferable property to be found at ballasted track, as it influences the stability and vertical alignment of the track was observed at low confinement pressure (less than $30 \mathrm{kPa}$ ) as shown in Fig. 9b.

Briefly, there is an agreement in the literature throughout large-triaxial testing about the significant of considering ballast confinement in the design and construction processes. Ballast confinement has a significant impact on reducing the vertical track settlement and raising the stability and stiffness of the track. Indraratna et al. [34, 84] recommended various approaches to increase the confinement of ballast layer like less sleeper spacings, higher shoulder ballast, inclusion of geotextiles materials, winged sleepers and using of periodic lateral resistant at different zones of the track.

Large scale triaxial testing was used in the literature to investigate the influence of cyclic loading frequency on the degradation and deformation of railroad ballast. From the literature, there is general agreement about the effect of loading frequency on the permanent deformation of railroad ballast via large scale triaxial testing; which is as loading frequency increases, the permanent deformation of ballast particles increases. Nevertheless, this can be reduced by optimizing PSD of ballast particles that develops better shear resistance which results in a lower permanent deformation of ballast particles at high loading frequency [27].

Indraratna et al. [57] observed that corner breakage of ballast particles occur at loading frequency in the range of $10-20 \mathrm{~Hz}$, while particle splitting of railroad ballast particles occur at loading frequency beyond $30 \mathrm{~Hz}$.

Sun et al. $[25,26]$ introduced new classifications of ballast particle breakage based on load frequency ( $f$ ). The authors observed that the higher the loading frequency, the more breakage and permanent deformation is occurred. This is due to the associated dynamic effects associated with high loading frequency. The three ranges are plastic shakedown (Range I) for $\mathrm{f}<20 \mathrm{~Hz}$, plastic shakedown and ratcheting (Range II) for $30<\mathrm{f}<50 \mathrm{~Hz}$ and plastic collapse (Range III) for $\mathrm{f}>60 \mathrm{~Hz}$. Range I is acceptable to be found in ballasted track as it produced less permanent deformation compared to Range II and III; where high possibility of track failure to occur, especially for train speed above $220 \mathrm{~km} / \mathrm{h}$. In 2018, Sun et al. [76] studied the effect of loading frequency and PSD on the resilience modulus

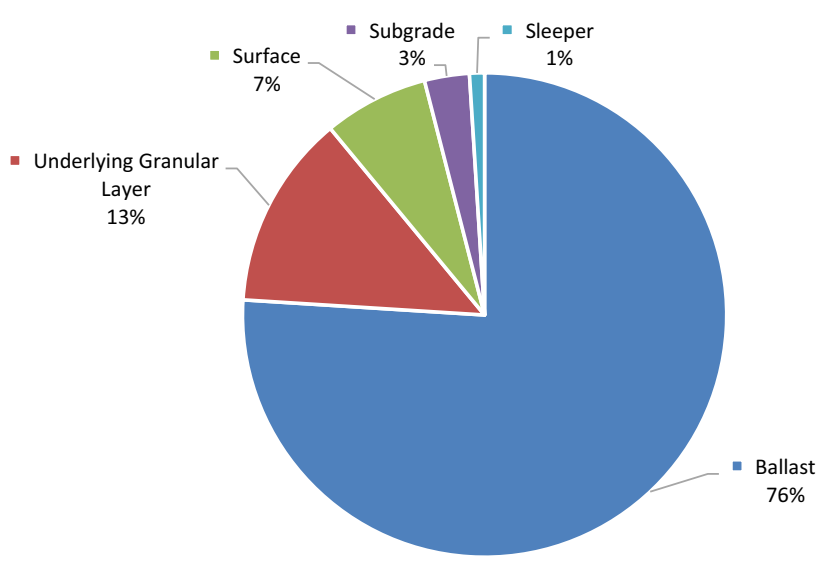

Fig. 10 Sources of fouling material reproduced from [9] 
of ballast layer using large scale triaxial test. The authors observed that as loading frequency increases, ballast resilience modulus decreases aside from PSD effect.

Selig [42] considered the significant influence of fouling on ballast layer when $10 \%$ or more of ballast aggregates are fine size aggregates. Selig and Waters [9] found that the fouling material sources for railroad ballast layer are different as shown in Fig. 10 Sources of fouling material reproduced from [9]. Selig and Waters [9] concluded that breakdown of ballast has the highest contribution to ballast fouling in North America. However, in British railways the biggest source to ballast fouling is external wagon spillage and airborne dirt [9]; while in Australian railways the coal infiltration is the main source of ballast fouling [85].

Ballast fouling degree can be measured by fouling index as well as it can be classified based on the fouling index. There are various fouling indices used in the literature. Selig and Waters [9] defined the fouling index (FI) as the summation of the percentage of weight of fouled material that passes through a $4.75 \mathrm{~mm}$ and $0.075 \mathrm{~mm}$ sieves. Ionescu [86] modified Selig and Waters' fouling index to outfit used ballast material in Australia as Selig and Waters defined their fouling index based on their study in North America. The previous indices are based only on the weight of fouling material. However, Feldman and Nissen [85] introduced the Percentage Void Contamination (PVC) ratio which include the variations of fouling material's specific gravity. PVC is the ratio of bulk fouling material volume to the clean ballast voids volume. But The authors did not consider the effect of particle size distribution of fouling material in their ratio. Indraratna et al. [87] introduced the Void Contaminant Index (VCl) which include the influence of many parameters like void ratio, specific gravity and particle size distribution of both fouling material and ballast.

Qian et al. [66] studied the influence of fouled ballast on the permanent deformation of ballast through cyclic large-scale triaxial test. The fouled ballast layer consists of ballast fine particles with $\mathrm{FI}=40$. The authors found that fouled ballast layer deformed by almost double value of axial strain compared to fresh ballast layer; due to the less contacts between large particles in fouled ballast layer.

Ngo et al. [29] studied the effect of clay fouling on ballast shear strength through monotonic triaxial testing. The authors studied the effect of different clay fouling levels $(10-50 \% \mathrm{VCl})$ under three confining pressures $(10,30$ and $60 \mathrm{kPa}$ ) on the shear behaviour of ballast. The authors found that clean ballast has the highest friction angle which decreases with the increase of clay fouling level at the same confining pressure. The authors concluded that fouling effect the volumetric behaviour of ballast. The more ballast is fouled with clay particles, the more is dilated under monotonic loading at the same confining pressure level.

Kashani et al. [47] investigated through monotonic large-scale triaxial test the influence of water content and fouling degree on the mechanical behavior of railroad ballast. The found that as water content increases the shear strength and elastic modulus of ballast decrease linearly with a rate dependent on fouling degree. The authors observed that fouling degree and water content influenced the rate of particle breakage under different confining pressure; low rate of particle breakage versus confining pressure for ballast with higher water content. The authors concluded that under constant water content and confining pressure, the high fouling degree increase the friction angle and strength of ballast layer. This is explained due to the less voids and large number of contacts between particles. The authors observe the same conclusion of Ngo et al. [29] regarding the volumetric change, High degree of ballast fouling, increase the dilation behavior of ballast at constant confining pressure.

After service, the ballast layer fouled with fine broken particles. The fouling condition decreases the performance of ballast layer. Geosynthetics have been used as enhancement element to increase the performance of ballast layer. There are different types and shapes of geosynthetics used to reinforce ballast layer. Form the literature, there is a considerable effort of experimental research work using large
Fig. 11 Different shapes of aperture geogrids a triaxialtriangular and $\mathbf{b}$ biaxialsquare [31]

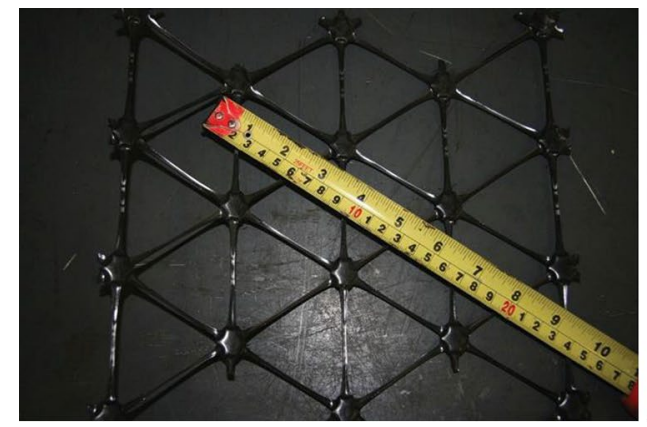

(a)

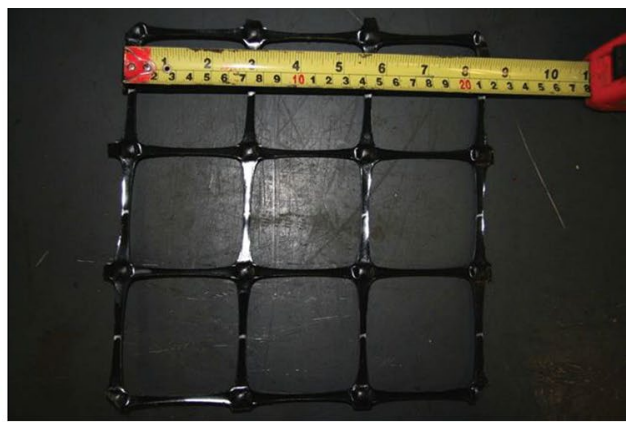

(b)

SN Applied Sciences 
scale triaxial test to understand the mechanical behavior of ballast layer reinforced with geosynthetics and their influence on the performance of the ballast layer, especially geogrids which are one of the most used geosynthetics material in enhancing the performance of ballast layer.

With regards to the role of the geogrid in enhancing the ballast performance, there is a general agreement in the literature about the positive influence of geogrids in enhancing the performance of the ballast layer through large scale triaxial testing. Qian et al. $[33,35,88]$ did a comparative study between biaxial and triaxial aperture geogrids (Fig. 11) through large scale triaxial test. The authors found that both aperture geogrids resulted in a better performance of ballast layer under cyclic loading. However, ballast layer reinforced with triaxial aperture geogrid had lower permanent deformation compared with ballast layer reinforced with biaxial aperture geogrids. This is due to the high resistance of ballast particles in the horizontal directions by triaxial aperture geogrid that leads to lower vertical settlement.

With regards to the placement location of the geogrid in the large scale triaxial test specimen, there are a variety of the placement locations used in the literature. Qian et al. $[33,35]$ placed the geogrid at the middle of the large scale triaxial test sample which corresponds to $305 \mathrm{~mm}$. Mishra et al. [31] observed through large scale triaxial testing that the maximum shear strength of ballast layer is achieved by using two geogrids at $254 \mathrm{~mm}$ from the top and bottom of sample for both triaxial and biaxial aperture geogrids. Similar observation was observed later by Qian et al. [88] in large scale triaxial testing of railroad ballast reinforced with geogrids using three configurations; one geogrid placed at the middle of test specimen, two geogrids placed at $150 \mathrm{~mm}$ from the top and the bottom of test specimen and two geogrids placed at 254 from the top and the bottom of test specimen.

\section{Large-scale box test}

It is an experimental approach to simulate the real field ballast behaviour and performance under traffic loading. Box test is introduced in the early 1980 s by Norman [89] and Gillian [90] where small box portion of real track is simulated by box test as illustrated by Lim [91] and shown in Fig. 12. The main purpose of large-scale box test is to get a rich understanding of the behaviour of railroad ballast under real field condition. For example, horizontal and

Fig. 12 Simulation area of box test

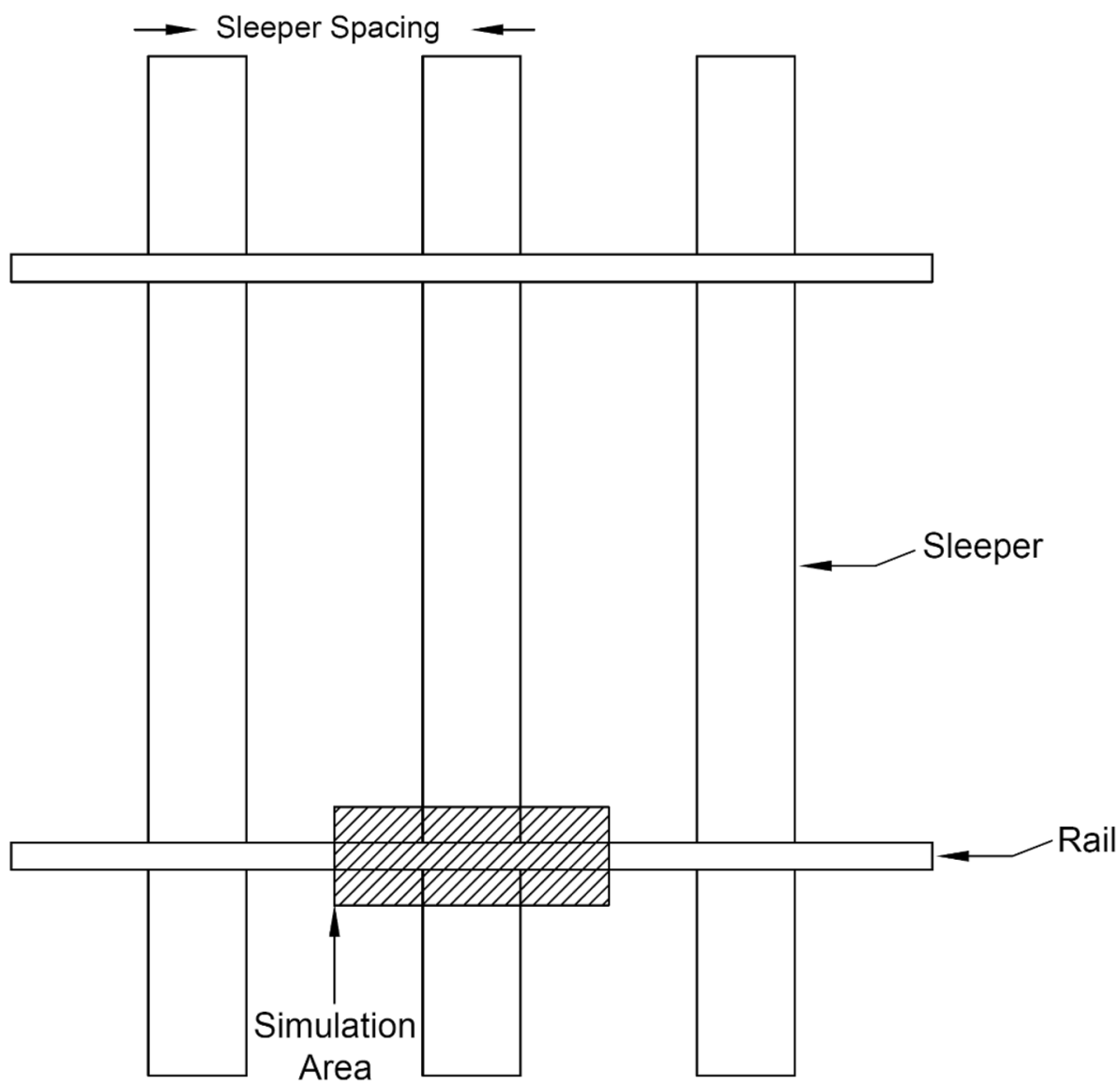


vertical settlement behavior of ballast layer under and away of the sleeper.

\subsection{Large scale equipment}

Although box test simulates a small portion of railway track, it needs a non-traditional large-scale equipment to be designed and developed. There are two main materials used to build the box; wood [89, 90, 92] and steel [93-98]. Some researchers $[91,99,100]$ used other transparent material like Perspex sheet to be used in one side of the steel box for better observation to the test sample during testing.

In the literature there are various number of box tests built and developed in a large-scale length to experimentally study the mechanical behaviour of railroad ballast under real traffic loadings. For example, box test built at the University of Massachusetts [89, 101], box test build by Gerald and Richard [102] as a part of collaborative research between Queen's University and Royal Military College, box test developed by Selig and Waters [9], box test build at the University of Nottingham [91, 103], box test designed and built at the University of Wollongong $[95,104]$ and box test designed and built by Al-Saoudi and Hassan [99].

Table 3 Sample size of box tests used in the literature to understand railroad ballast behaviour

\begin{tabular}{ll}
\hline Material & References \\
\hline $1000 \times 800 \times 600$ & {$[93]$} \\
$800 \times 600 \times 650$ & {$[95-98]$} \\
$800 \times 600 \times 600$ & {$[94,104,106]$} \\
$700 \times 300 \times 450$ & {$[91,100,113]$} \\
$600 \times 300 \times 450$ & {$[99]$} \\
$400 \times 200 \times 300$ & {$[107]$} \\
$300 \times 600 \times 475$ & {$[9,89,90,92]$} \\
\hline
\end{tabular}

\subsection{Sample Size}

The sample size of railroad ballast used in box test is the size of the box. From the literature, the mostly used box shape in the literature is rectangular prism with different sizes as shown in Table 3. The size of the box depends on the simulation area of the track which is specified by the researcher based on the research resources. There are no details in the literature about the selection standards of box size compared to sample size used in large scale triaxial test. Most of the researcher used the width of the box similar to the sleeper spacing $(600-800 \mathrm{~mm})$. Regarding the height of the box, most researchers used the typical ballast height (300-450 mm). Other researches built a higher box to consider the other components of track substructure like sub ballast and sub grade. Regarding the length of the box, there is a variety of box's lengths used in the literature; further investigation is required to study the influence of box's length on the result accuracy.

\subsection{Loading condition}

As discussed above, track substructure is exposed to different types of loading; static, cyclic and impact loadings. From the literature, most of the studies related to railroad ballast testing through box test applies a pure continuous loading (cyclic loading) with certain frequency as shown in Table 4. The magnitude of the sinusoidal loading represents the axle/wheel load and the frequency represents the train speed. There are few studies applies a constant lateral pressure that represents the self-confinement of ballast in the field through box test as shown in Table 4 . Alabbasi [105] studied the influence of simulated train loading on the mechanical behavior of railroad ballast using Discrete Element Modelling (DEM) through box test. The author studied the mechanical behavior under sinusoidal loading and a more realistic simulated train loading utilizing the Beam on Elastic Foundation (BOEF)
Table 4 Applied loading conditions in box test for railroad ballast

\begin{tabular}{llll}
\hline Vertical load & \multicolumn{2}{l}{ Lateral pressure } & References \\
\cline { 1 - 3 } Magnitude & Frequency & \\
\cline { 1 - 2 } Sinusoidal load of with magnitude $16.1 \mathrm{kN}$ & $6 \mathrm{~Hz}$ & - & {$[93]$} \\
Sinusoidal load with magnitude of $73 \mathrm{and} 88 \mathrm{kN}$ & $15 \mathrm{~Hz}$ & - & {$[104]$} \\
Sinusoidal load with magnitude of $73 \mathrm{kN}$ & 15 & 7 and $10 \mathrm{kPa}$ & {$[106]$} \\
Sinusoidal load with magnitude of $40 \mathrm{kN}$ & $3 \mathrm{~Hz}$ & - & {$[100]$} \\
Sinusoidal load with magnitude of $477 \mathrm{kPa}$ & 15 & 7 and $10 \mathrm{kPa}$ & {$[94]$} \\
Sinusoidal load with magnitude of $10,20,25,30$ and $40 \mathrm{kN}$ & $3 \mathrm{~Hz}$ & - & {$[99]$} \\
Sinusoidal load with magnitude of $200 \mathrm{kPa}$ and 300 & $4 \mathrm{~Hz}$ & - & {$[107]$} \\
Sinusoidal load with magnitude of $225 \mathrm{kN}$ & $20 \mathrm{~Hz}$ & $10 \mathrm{kPa}$ & {$[95-98]$} \\
Sinusoidal load with magnitude of $260 \mathrm{kN}$ & $10 \mathrm{~Hz}$ & - & {$[108]$} \\
Sinusoidal load with magnitude of $30 \mathrm{kN}$ & $3 \mathrm{~Hz}$ & - & {$[113]$} \\
\hline
\end{tabular}


theory via DEM. However, further experimental investigations are required to understand the mechanical behavior of railroad ballast under a more realistic train loading.

Nevertheless, the actual train loading is not a pure continuous sinusoid. The train consists of a number of cars. Each car has typically four axles with different spacing. Each axle exerts a load on ballast layer. The loading from the train is not a pure sinusoidal and depends on different parameters. For instance, car length, car weight, axle spacing and time between passing trains. Therefore, it is significant to test the ballast behavior through box test under a more realistic train loading including the impact loads (dynamic effects) generated from track/vehicle irregularities for better representation of field conditions and results accuracy.

\subsection{Ballast material}

As discussed above Sect. 2.6 that ballast aggregates are a result of crushed rocks, which is known as parent rocks. It is significant to know the type and properties of the ballast parent rocks which influences the ballast properties. There are different types of ballast parent rocks as described previously. The most used parent rock for railroad ballast is extrusive igneous rocks followed by metamorphic then sedimentary rocks.

From the literature, there are various types of ballast material used in the box testing of railroad ballast. For example, latite basalt [94-98, 104, 106], granite [91, 100], granodiorite [91, 107], dolomite [9] limestone [102], and quartzite [108].

From the literature, there is low effort of research done in studying and understanding the influence of ballast material type on the mechanical behavior via box test. It is significant to do a comparative study through box test for different ballast materials to understand the influence of ballast material type on the mechanical behavior (e.g. settlement and particle breakage). This leads to better material type to be implemented in ballasted tracks which has the future potential to decrease the requirements of periodical maintenance operation.

\subsection{Main findings of understanding ballast behavior using box test}

From the literature, large scale box tests have been used to understand the mechanical behaviour of railroad ballast under a more realistic and closer to field condition, where a box of track is simulated. Most of the studies related to large scale box testing of ballast was used to understand the deformation, degradation and displacement behaviours of railroad ballast with considering the effect of fouling and reinforcement materials.

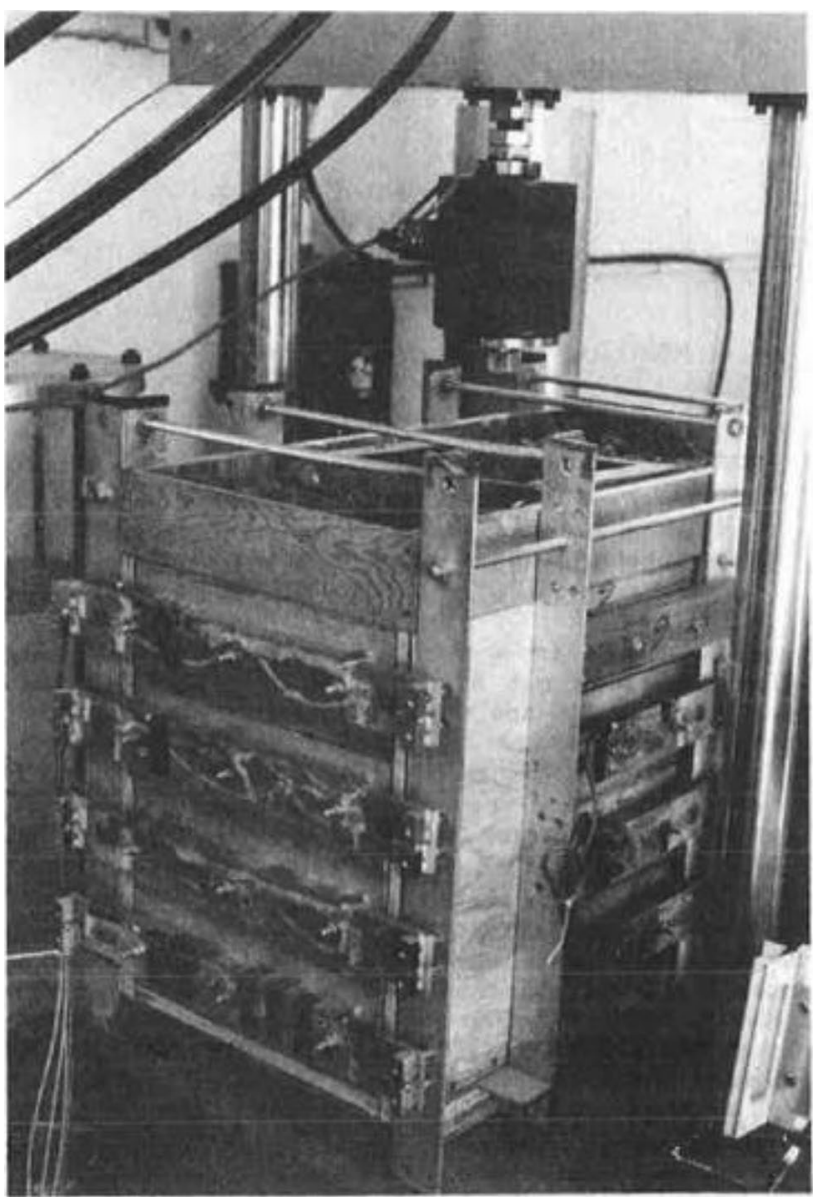

Fig. 13 Wooden box apparatus designed and built at the University of Massachusetts [92]

In 1982, Norman [89] introduced box test as a laboratory approach to study the mechanical behaviour of railroad ballast under simulated traffic loadings. The author designed and built a small wooden box test with steel angle reinforcement at the University of Massachusetts (Fig. 13). Crushed trap rock was used for ballast material. Ballast confinement was simulated by using different types and arrangements of rubber linings. The box was relatively small. The purpose of the test was to understand the horizontal ballast stresses developed under cyclic loadings. In 1996, a new different box test is built at the same university (University of Massachusetts) by Ref. [101]. It has the same dimension of the previous one, but it was built with different material using metal sheets and welded iron angles as a reinforcement. Their purpose was to study the mechanical behaviour of fouled railroad ballast under large number of cyclic loading.

Selig and Waters [9] studied the effect of traffic loading on ballast horizontal stress as shown in Fig. 14. This was done by using number of horizontal sensors attached on the lateral walls of the box. The authors observed by using 


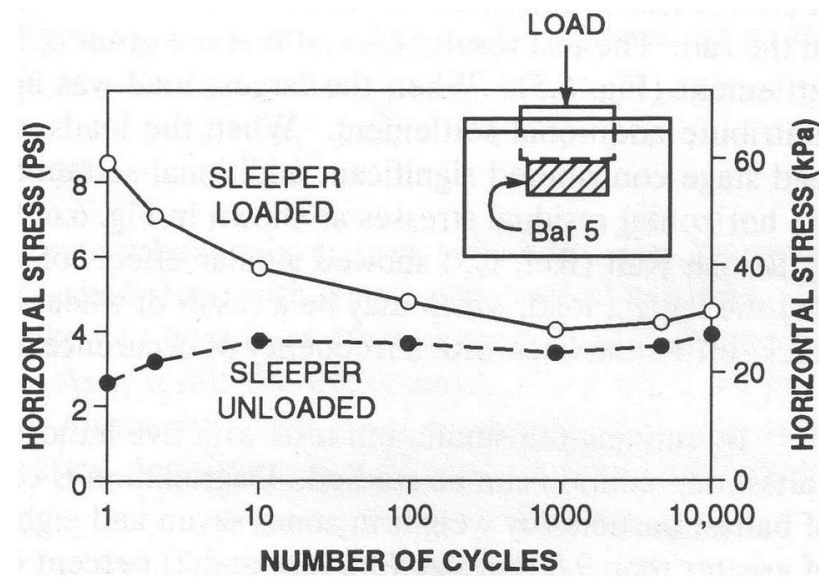

Fig. 14 Effect of repeated load on horizontal stress in box test [9]

a dye on ballast particles that particle breakage is mostly occurred under the sleeper.

Anderson and Key [93] built a large scale box model consists of steel box and reinforced concrete sleeper restrained by two arms (Fig. 15). The sinusoidal cyclic loading was applied on the sleeper by a hydraulic ram. The purpose of their model is to evaluate the mechanical behaviour of two ballast layer bed after stoneblowing maintenance approach under repeated loading. Where two ballast layers are created from stoneblowing. The first layer is the original dense ballast and the second layer is the newly added particles by stoneblower. The authors found that stoneblowing maintenance method is better than tamping as it improves ballast performance under cyclic loading.

Most of the previous box tests were not considered the effect of ballast self-confinement. Indraratna and lonescu [104] built a large scale box apparatus with movable sides to simulate the triaxial condition applied on ballast layer in the real track caused by the traffic loading and adjacent ballast confinement. The authors called their model as large prismoidal triaxial apparatus. The authors used hydraulic actuator for the application of normal stress and two hydraulic jacks for the application of lateral stress as shown in Fig. 16. The authors studied the influence of cyclic loading on ballast and capping settlement in the long and short directions of sleeper as shown in Fig. 17. The authors concluded that more than $60 \%$ of the total settlement was from ballast layer deformation under cyclic loading. Salim [106] used the same equipment to study the deformation and degradation of fresh and recycled ballast under cyclic loading. The authors showed experimentally the significance of using three types of geosynthetics (geogrid, geocomposite and woven-geotextile) as reinforcement for recycled ballast. The authors observed that recycled ballast exposed more to particle breakage than fresh ballast under cyclic loading. The authors concluded that all geosynthetics decreased the amount of particle breakage. The authors found that geocomposite is a recommended geosynthetics material to be used in wet conditions compared to others. Because it positively influenced the settlement performance of recycled ballast behaviour under wet condition more than others.

Indraratna and Nimbalkar [94] used the same apparatus to study the influence of using geosynthetics reinforcement on ballast deformation and degradation behaviours. The authors found that biaxial geogrid reduced ballast degradation and deformation compared to geotextile membrane, which was explained by the authors that this is due to the strong interlocking between ballast and geogrid. In 2014, the same apparatus was used to investigate the mechanical behaviour of sub ballast reinforced with geocells by Indraratna et al. [109] and Ngo Ngoc et al. [110] under different confining

Fig. 15 Large scale box equipment [93]

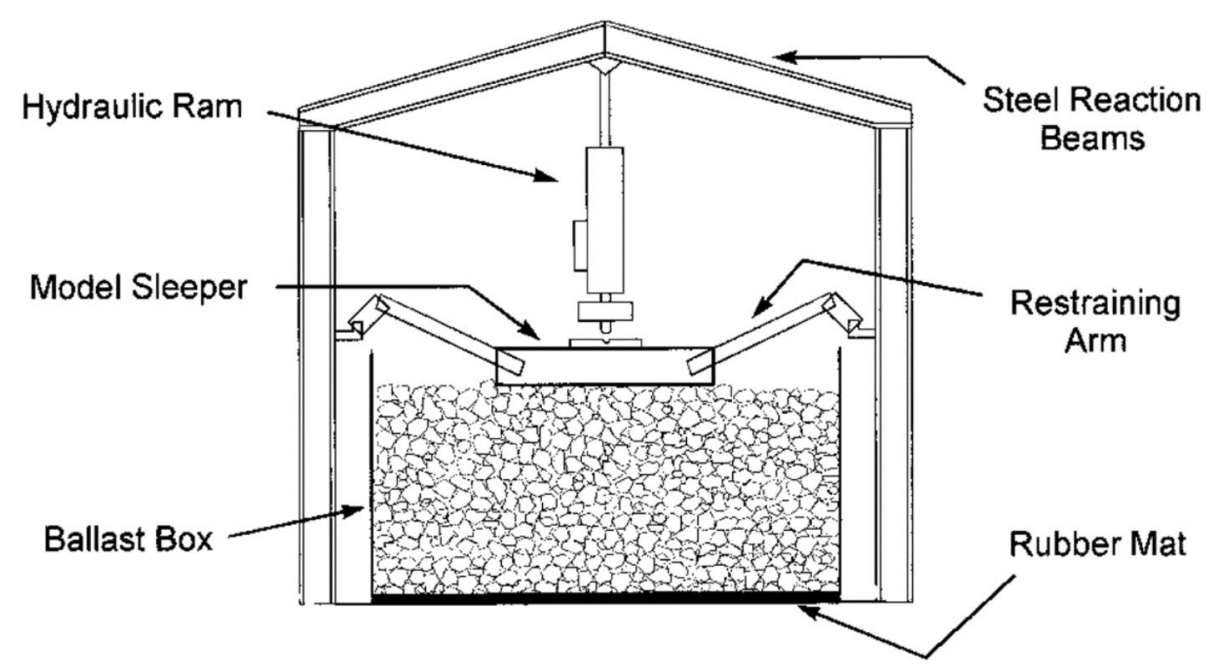


Fig. 16 Triaxial box test apparatus designed and built at University of Wollongong by Indraratna and lonescu [104]

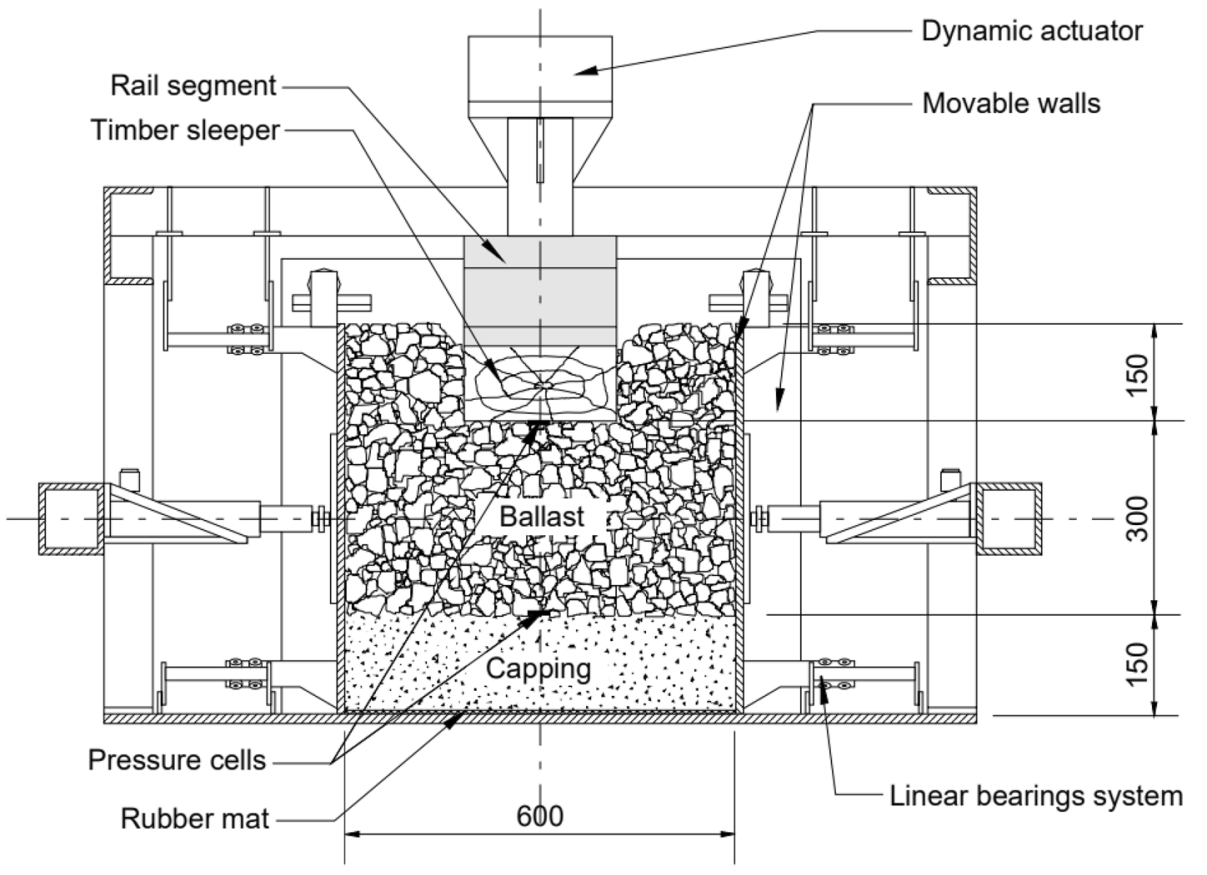

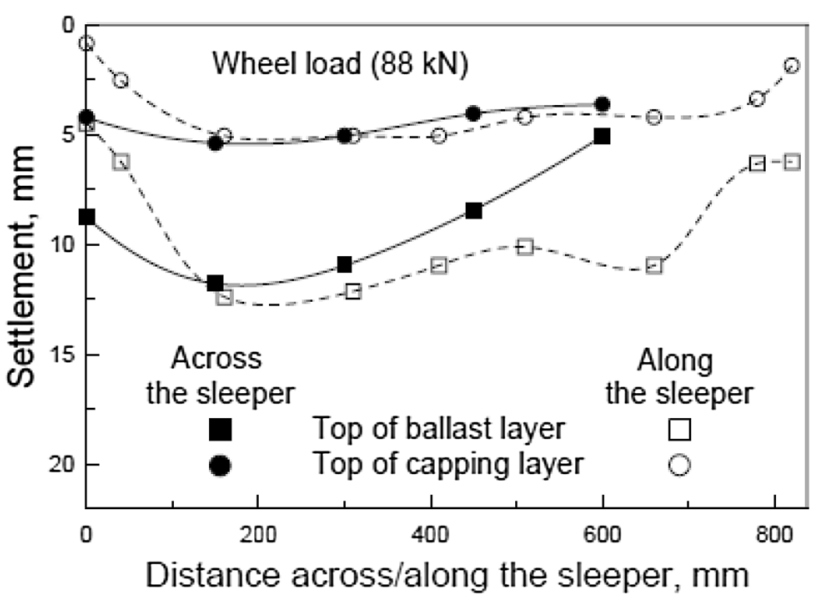

Fig. 17 Settlement of ballast and capping layers across and along the sleeper [104]

pressures and cyclic loading frequencies. The authors observed a reduction in the vertical settlement (by almost 12-25\%) and volumetric strain of sub ballast layer due to the offered confinement by geocells, especially at low confinement (less than $15 \mathrm{kPa}$ ) and high cyclic loading frequency (more than $20 \mathrm{~Hz}$ ). The authors found that the usage of geocell reinforcement for sub ballast increases the allowable train speed by almost 5-25\%.

Indraratna et al. [95] modified the large prismoidal triaxial apparatus to study lateral displacement of ballast layers with and without geogrid. The authors called their modified model as process simulation test apparatus.
Their modification included the introduction of five movable plates at one side of the box as shown in Fig. 18 . Other studies $[96,97]$ used this apparatus to study the influence of geogrid reinforcement on ballast lateral settlement. The authors showed the significance of using geogrid in reducing ballast lateral settlement.

Lim [91] and McDowell et al. [111] designed a box test by which ballast degradation and deformation can be visualized during the test. The box was built as a steel case with one side (longer side) as reinforced Perspex (transparent material) as shown in Fig. 19. Lim [91] did the test for six different ballast material that matched to Railtrack Line Specification (RT/CE/S/006 Issue 3, 2000). The authors observed that particle breakage occurred mostly beneath the sleeper under cyclic loading.

Several researchers in the literature used large scale box test to investigate the different reinforcement techniques that are used to enhance the performance of ballast layer under repetitive loading. McDowell and Stickley [100] used the same apparatus of Lim [91] and McDowell et al. [111] to investigate the behaviour of railroad ballast with geogrid reinforcement. The authors found that the size of geogrid aperture effect the behaviour of railroad ballast under cyclic loading. Sol-Sánchez et al. [107] used the box test to show the advantage of mixing rubber crumb resulted from used tires with ballast by different volume percentages $(5 \%, 10 \%, 20 \%$ and $30 \%)$ in developing ballast performance under cyclic loading (Fig. 20). The authors found that rubber crumb influenced ballast vertical settlement, vertical stiffness, energy dissipation and particle breakage. The authors 


\section{East wall of the existing apparatus that has been modified}

(a)

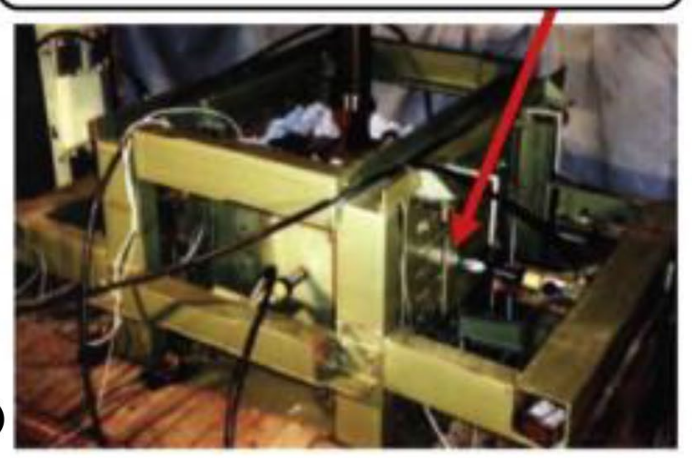

(b)

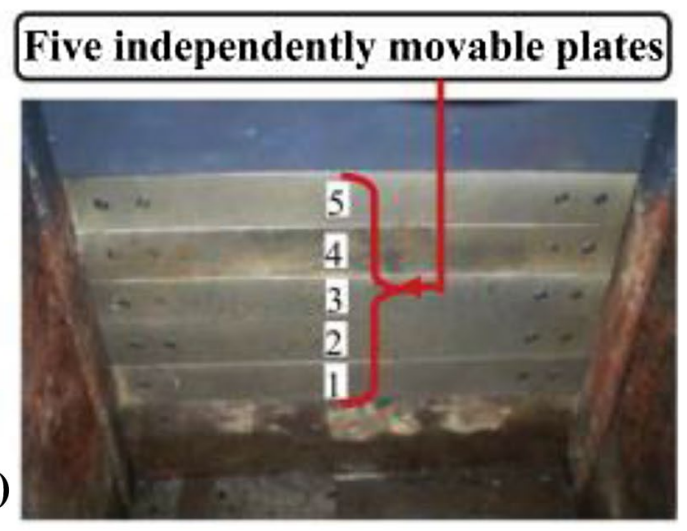

(c)
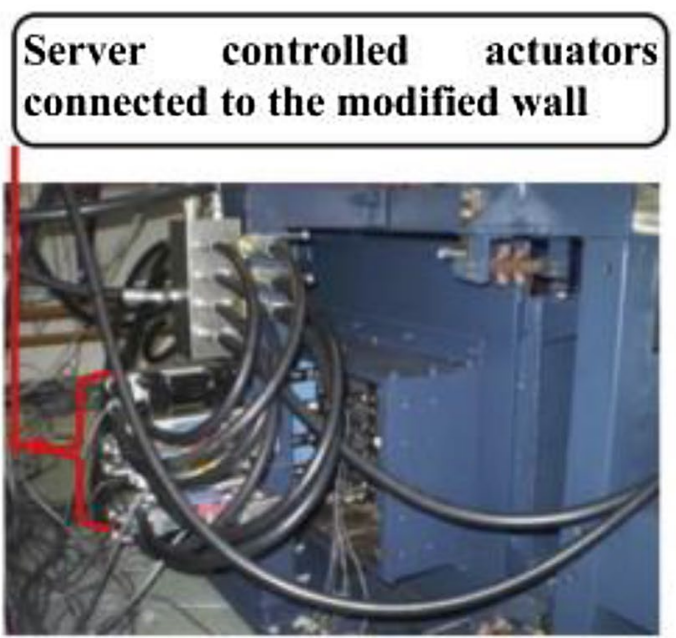

(d)

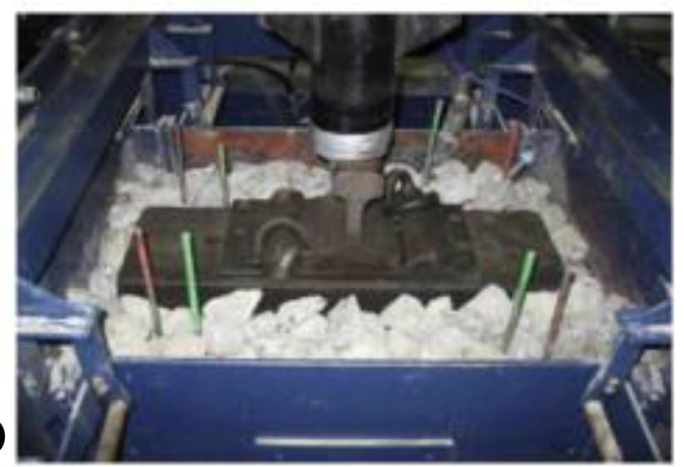

Fig. 18 Modified triaxial box apparatus a the modified side wall, $\mathbf{b}$ arrangement of five movable plate, $\mathbf{c}$ setup of actuators used to apply confinement on the five plates and $\mathbf{d}$ top view of the apparatus [95]

Fig. 19 Box test set-up a top view and $\mathbf{b}$ side view [91]

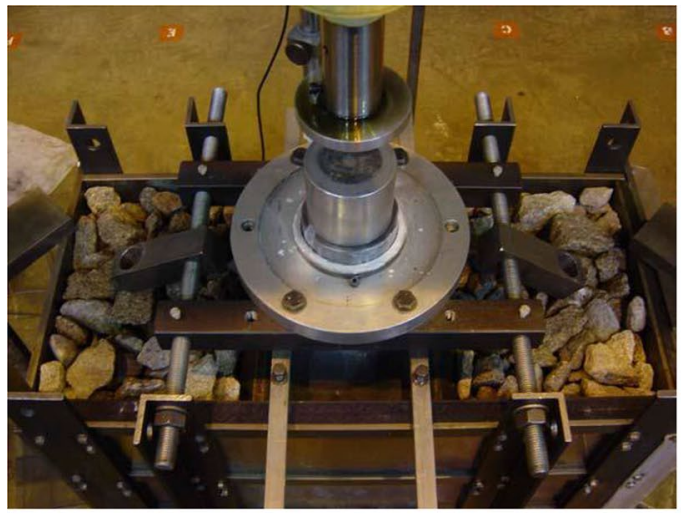

(a)

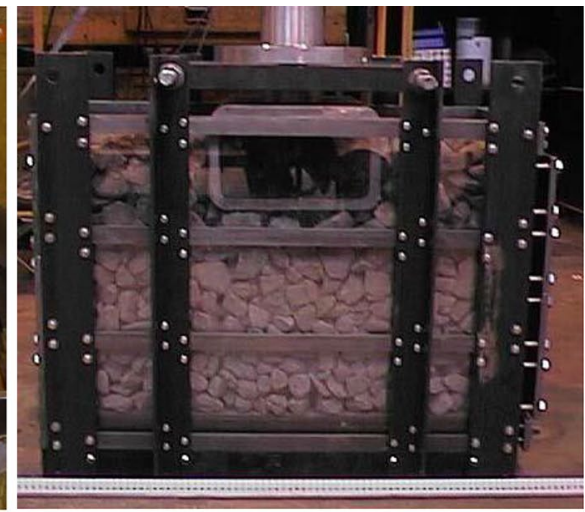

(b) recommended that optimum volume of rubber crumb should be $10 \%$ of ballast volume, where ballast vertical displacement and energy dissipation is minimum. The authors observed that large volume percentages of rubber crumb $>10 \%$ of ballast volume enhanced the vertical stiffness and reduced particle breakage of ballast layer. However, large volume percentages of rubber crumb increased vertical displacement and energy 
Fig. 20 Different percentages of rubber crumb mixed with ballast and large scale box test set up $[107,133]$
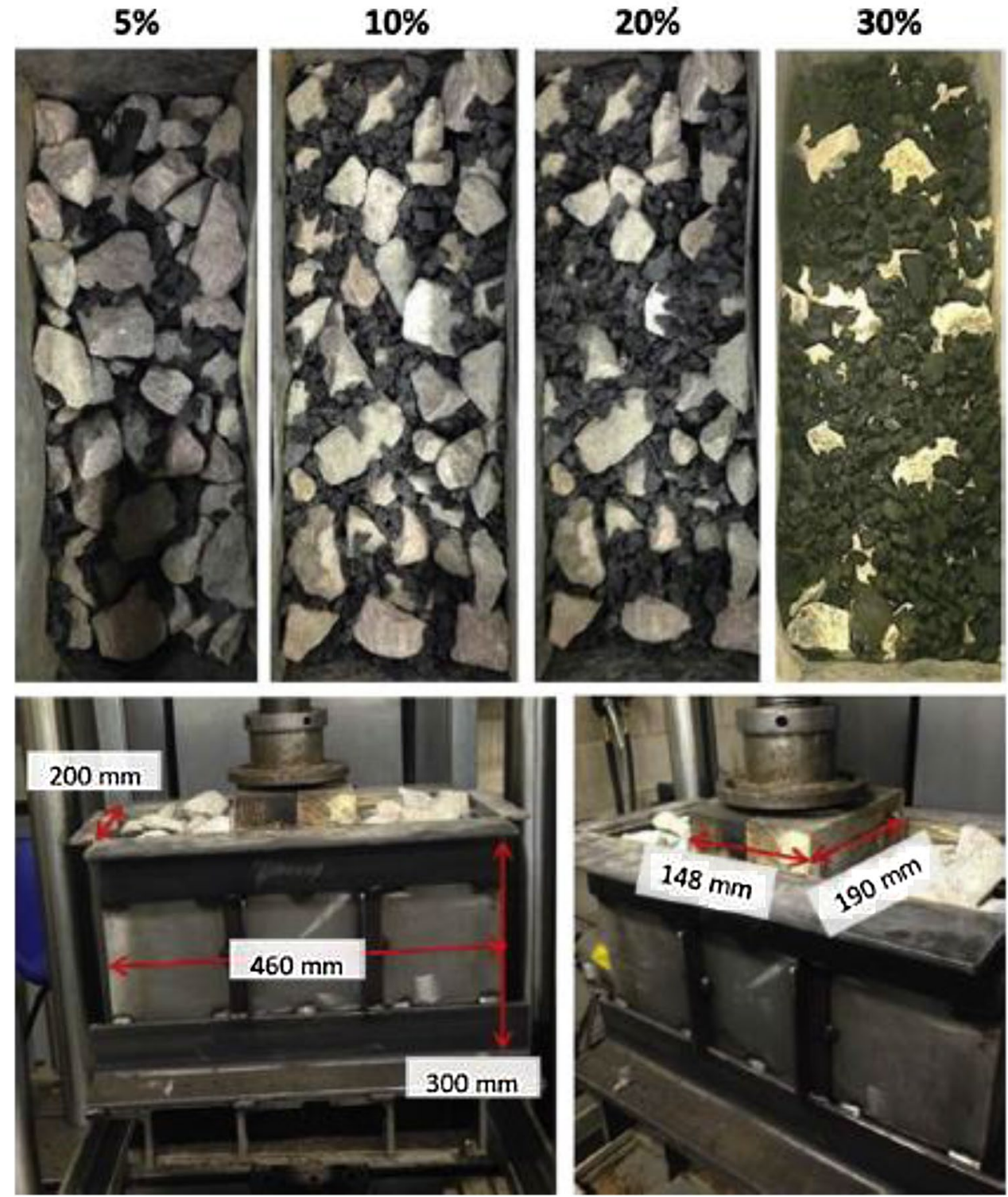

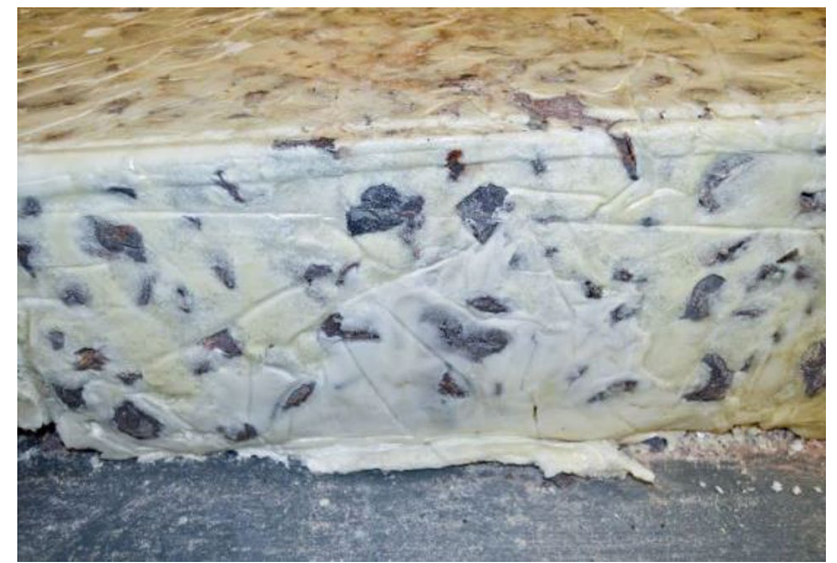

Fig. 21 Completely reinforced ballast layer with rigid polyurethane foam [108] dissipation of ballast layer. Du Plooy and Gräbe [108] showed by number of box tests the advantages of reinforcing ballast with rigid polyurethane foam as shown in Fig. 21. The authors studied the influence of reinforcement volume percentages ( $0 \%, 50 \%$ and $100 \%)$ on ballast settlement behaviour. The authors concluded that rigid polyurethane foam reinforcement reduced ballast layer settlement significantly.

\section{Conclusion}

Ballasted railway tracks have been used intensively around the world. Ballast is the basic component of a ballasted track. Ballast layer deforms and degrades under repetitive traffic loading. Therefore, periodical maintenance of the ballast 
layer is required which is costly and time-consuming activity. This raises the research interest in the literature about understanding ballast mechanical behaviour for better ballast layer design and efficient periodical maintenance. From the literature, large scale experimental testing has been used intensively to understand the mechanical behavior of railroad ballast, more frequently through the large scale triaxial and box tests. This paper reviewed the state of art of the literature on the large scale triaxial and box tests that are used to evaluate and understand the mechanical behaviour of railroad ballast. The paper presented a review on the key findings about understanding ballast behaviour from both tests and the necessity for future work.

Large scale triaxial test is used to develop the understanding ballast mechanical properties like shear strength, angle of friction, shear stress-strain behaviour and volumetric change behavior under a triaxial conditions. Box test is used to get a rich understanding about the behaviour of ballast under a more realistic field situation like vertical displacement of the fresh and fouled ballast under and away from the sleeper. Both tests provide a rich understanding of ballast mechanical behavior and are considered as the most representative to real field scenario.

Further investigations are required to investigate the influence of ballast material type on the mechanical behavior of railroad ballast through large scale triaxial and box tests for better ballast material selection and efficient maintenance. Moreover, it is recommended to use a more realistic loading application that represents train loading including the dynamic effects instead of pure continuous sinusoidal or haversine, for better and accurate understanding of ballast behaviour using large scale triaxial and box tests. Further research work is required to investigate the mechanical behaviour under impact loads via large scale triaxle and box tests. Furthermore, further large-scale experimental investigations are required to optimize the long term behavior of railroad ballast like system optimization of ballast grading and energy absorbing foundation.

Acknowledgements Open Access funding provided by the Qatar National Library. This work has been carried out under a research project entitled "Framework for Research on Railway Engineering" which is supported by a grant sponsored by Qatar Rail with a Grant Reference Number: QUEX-CENG-Rail 17/18.

Funding This study was funded by Qatar Rail with a Grant Reference Number: QUEX-CENG-Rail 17/18.

\section{Compliance with ethical standards}

Conflict of interest The authors declare that they have no conflict of interest.
Intellectual property rights This manuscript was part of Master Thesis [105], which the correspondent author is the owner and copyright holder of this Thesis.

Open Access This article is distributed under the terms of the Creative Commons Attribution 4.0 International License (http://creativeco mmons.org/licenses/by/4.0/), which permits unrestricted use, distribution, and reproduction in any medium, provided you give appropriate credit to the original author(s) and the source, provide a link to the Creative Commons license, and indicate if changes were made.

\section{References}

1. Givoni M, Brand C, Watkiss P (2009) Are railways 'climate friendly'? Built Environ 35(1):70-86

2. Givoni M (2007) Environmental benefits from mode substitution: comparison of the environmental impact from aircraft and high-speed train operations. Int J Sustain Transp 1(4):209-230

3. Song $M$ et al (2016) Railway transportation and environmental efficiency in China. Transp Res Part D Transp Environ 48:488-498

4. Savolainen VV, Hilmola OP (2009) The relative technical efficiency of European transportation systems concerning air transport and railways. Int J Bus Perform Manag 11(1-2):19-42

5. Li D et al (2015) Railway geotechnics. CRC Press, London

6. Gautier PE (2015) Slab track: review of existing systems and optimization potentials including very high speed. Constr Build Mater 92:9-15

7. Esveld C (2001) Modern railway track. MRT Press, Zaltbommel

8. Blanco-Lorenzo J et al (2011) Dynamic comparison of different types of slab track and ballasted track using a flexible track model. Proc Inst Mech Eng Part F J Rail Rapid Transit 225(6):574-592

9. Selig ET, Waters JM (1994) Track geotechnology and substructure management. Thomas Telford, London

10. Indraratna B, lonescu D, Christie HD (1998) Shear behavior of railway ballast based on large-scale triaxial tests. J Geotech Geoenviron Eng 124(5):439-449

11. Sañudo $R$ et al (2016) Track transitions in railways: a review. Constr Build Mater 112:140-157

12. McDowell GR, Lim WL, Collop AC (2003) Measuring the strength of railway ballast. Ground Eng 36(1):25-28

13. Shenton MJ (1978) Deformation of railway ballast under repeated loading conditions. In: Kerr AD (ed) Railroad track mechanics and technology. Pergamon, Oxford, pp 405-425

14. Raymond GP, Bathurst RJ (1994) Repeated-load response of aggregates in relation to track quality index. Can Geotech J 31(4):547-554

15. Skoglund KA (2002) A study of some factors in mechanistic railway track design. Department of Road and Railway Engineering, Norwegian University of Science and Technology, $p$ 260

16. Key AJ (1999) Behaviour of two layer railway track ballast under cyclic and monotonic loading

17. Suiker AS, Selig ET, Frenkel R (2005) Static and cyclic triaxial testing of ballast and subballast. J Geotech Geoenviron Eng 131(6):771-782

18. Lackenby J et al (2007) Effect of confining pressure on ballast degradation and deformation under cyclic triaxial loading. Géotechnique 57(6):527-536 
19. Anderson WF, Fair P (2008) Behavior of railroad ballast under monotonic and cyclic loading. J Geotech Geoenviron Eng 134(3):316-327

20. Sevi AF, Ge L, Take WA (2009) A large-scale triaxial apparatus for prototype railroad ballast testing. Geotech Test J 32(4):297-304

21. Aursudkij B, McDowell G, Collop A (2009) Cyclic loading of railway ballast under triaxial conditions and in a railway test facility. Granul Matter 11(6):391

22. Nålsund R (2010) Effect of grading on degradation of crushedrock railway ballast and on permanent axial deformation. Transp Res Rec J Transp Res Board 2154:149-155

23. Mishra D et al (2013) Characterization of railroad ballast behavior under repeated loading: results from new large triaxial test setup. Transp Res Rec J Transp Res Board 2374:169-179

24. Indraratna B et al (2013) Behaviour of clay-fouled ballast under drained triaxial testing. Geotech Int J Soil Mech 63(5):410-419

25. Sun Q, Indraratna B, Nimbalkar S (2014) Effect of cyclic loading frequency on the permanent deformation and degradation of railway ballast. Géotechnique

26. Sun QD, Indraratna B, Nimbalkar S (2015) Deformation and degradation mechanisms of railway ballast under high frequency cyclic loading. J Geotech Geoenviron Eng 142(1):04015056

27. Indraratna B, Sun Y, Nimbalkar S (2016) Laboratory assessment of the role of particle size distribution on the deformation and degradation of ballast under cyclic loading. J Geotech Geoenviron Eng 142(7):04016016

28. Bian X et al (2016) Cyclic and postcyclic triaxial testing of ballast and subballast. J Mater Civ Eng 28(7):04016032

29. Ngo NT, Indraratna B, Rujikiatkamjorn C (2016) Micromechanics-based investigation of fouled ballast using large-scale triaxial tests and discrete element modeling. J Geotech Geoenviron Eng 143(2):04016089

30. Fair P (2004) The geotechnical behaviour of ballast materials for railway track maintenance. University of Sheffield

31. Mishra D et al (2014) Investigation of geogrid-reinforced railroad ballast behavior using large-scale triaxial testing and discrete element modeling. Transp Res Rec J Transp Res Board 2462:98-108

32. Indraratna B, Sun QD, Nimbalkar S (2014) Observed and predicted behaviour of rail ballast under monotonic loading capturing particle breakage. Can Geotech J 52(1):73-86

33. Qian Y et al (2015) Characterization of geogrid reinforced ballast behavior at different levels of degradation through triaxial shear strength test and discrete element modeling. Geotext Geomembr 43(5):393-402

34. Indraratna B, Lackenby J, Christie D (2005) Effect of confining pressure on the degradation of ballast under cyclic loading. Géotechnique 55(4):325-328

35. Qian Y et al (2013) Comparative evaluation of different aperture geogrids for ballast reinforcement through triaxial testing and discrete element modeling. In: Proceedings of geosynthetics

36. Suiker ASJ (2002) The mechanical behaviour of ballasted railway tracks. Technische Universiteit Delft (The Netherlands), Ann Arbor, p 237

37. Aursudkij B (2007) A laboratory study of railway ballast behaviour under traffic loading and tamping maintenance. University of Nottingham

38. Trinh VN et al (2012) Mechanical characterisation of the fouled ballast in ancient railway track substructure by large-scale triaxial tests. Soils Found 52(3):511-523

39. Qian Y et al (2018) Role of initial particle arrangement in ballast mechanical behavior. Int J Geomech 18(3):04017158

40. Indraratna B (1996) Large-scale triaxial facility for testing nonhomogeneous materials including rockfill and railway ballast. Aust Geomech 30:125-126
41. Skoglund K, Hoseth S, Værnes E (2000) Development of a large triaxial cell apparatus with variable deviatoric and confining stresses. Unbound Aggreg Road Constr UNBAR 4:145-152

42. Selig ET (1985) Ballast for heavy duty track. In:Track technology. Thomas Telford Publishing, pp 245-252

43. Sekine E, Kono A, Kito A (2005) Strength and deformation characteristics of railroad ballast in ballast particle abrasion process. Q R RTRI 46(4):256-261

44. Ebrahimi A, Tinjum JM, Edil TB (2012) Protocol for testing fouled railway ballast in large-scale cyclic triaxial equipment. Geotech Test J 35(5):796-804

45. Indraratna B, Wijewardena LSS, Balasubramaniam AS (1993) Large-scale triaxial testing of greywacke rockfill. Geotechnique 43(1):37-51

46. Marschi ND, Chan CK, Seed HB (1972) Evaluation of properties of rockfill materials. J Soil Mech Found Div 98(1):95-114

47. Faghihi Kashani H, Ho CL, Hyslip JP (2018) Fouling and water content influence on the ballast deformation properties. Constr Build Mater 190:881-895

48. Bishop AW, Green GE (1965) The influence of end restraint on the compression strength of a cohesionless soil. Geotechnique 15(3):243-266

49. Duncan JM, Dunlop P (1900) The significance of cap and base restraint. J Soil Mech Found Div 92:271-290

50. Ferellec J-F et al (2017) Analysis of compaction of railway ballast by different maintenance methods using DEM, vol 140, $p$ 15032

51. Kolisoja $P$ (1997) Factors affecting deformation properties of coarse grained granular materials. In: The international conference on soil mechanics and foundation engineering, International Society for Soil Mechanics and Foundation Engineering. AA Balkema

52. Qian Y et al (2013) Simulating ballast shear strength from largescale triaxial tests: discrete element method. Transp Res Rec J Transp Res Board 2374:126-135

53. Anderson WF et al The deformation behavior of two layer railway ballast beds. AA Balkema Publishers

54. Garg N, Thompson M (1997) Triaxial characterization of Minnesota Road Research project granular materials. Transp Res Rec J Transp Res Board 1577:27-36

55. Toan DV (1975) Effects of basecourse saturation on flexible pavement performance

56. Selig ET, Alva-Hurtado JE. Predicting effects of repeated wheel loading on track settlement

57. Indraratna B, Thakur PK, Vinod JS (2010) Experimental and numerical study of railway ballast behavior under cyclic loading. Int J Geomech 10(4):136-144

58. Dupla J-C et al (2007) Mechanical behaviour of coarse grained soils reference. Bulletin de Liaison des Laboratoires des Ponts et Chaussées 268(269):1-58

59. Sheng X, Jones CJC, Thompson DJ (2003) A comparison of a theoretical model for quasi-statically and dynamically induced environmental vibration from trains with measurements. J Sound Vib 267(3):621-635

60. Jones CJC, Block JR (1996) Prediction of ground vibration from freight trains. J Sound Vib 193(1):205-213

61. Remennikov AM, Kaewunruen S (2008) A review of loading conditions for railway track structures due to train and track vertical interaction. Struct Control Health Monit 15(2):207-234

62. Kaewunruen S, Remennikov A (2008) Dynamic properties of railway track and its components: a state-of-the-art review

63. Lee ML (2005) A numerical study into the reconstruction of impact forces on railway track-like structures, vol 4, pp 19-45

64. Sun Y, Zheng C (2017) Breakage and shape analysis of ballast aggregates with different size distributions. Particuology 35:84-92 
65. Sun Y, Chen C, Nimbalkar S (2017) Identification of ballast grading for rail track. J Rock Mech Geotech Eng 9(5):945-954

66. Qian Y et al (2014) Effects of ballast degradation on permanent deformation behavior from large-scale triaxial tests

67. Li D (1994) Railway track granular layer thickness design based on subgrade performance under repeated loading. University of Massachusetts Amherst, Ann Arbor, p 317

68. Sadeghi J, Zakeri JA, Najar MEM (2016) Developing track ballast characteristic guideline in order to evaluate its performance. Int J Railw 9(2):27-35

69. Watters BR, Klassen MJ, Clifton AW (1987) Evaluation of ballast materials using petrographic criteria

70. Johansson E, Lukschová Š, Miškovský K (2011) Petrographic characteristics of granitoid and gabbroid intrusive rocks as a tool for evaluation of mechanical properties. Technological properties of rock aggregates. PhD thesis, Luleå University of Technology, Luleå, Sweden

71. Raymond GP (1985) Research on railroad ballast specification and evaluation. Transp Res Rec 1006:1-8

72. Indraratna B (2016) 1st Ralph Proctor Lecture of ISSMGE. Railroad performance with special reference to ballast and substructure characteristics. Transp Geotech. 7:74-114

73. Indraratna B, Salim W (2005) Mechanics of ballasted rail tracks: a geotechnical perspective. CRC Press, Boca Raton

74. Selig ET, Roner CJ (1987) Effects of particle characteristics on behavior of granular material. Transp Res Rec (1131)

75. Raymond GP, Diyaljee VA (1979) Railroad ballast sizing and grading. J Geotech Geoenviron Eng 105:676-681

76. Sun Y, Nimbalkar S, Chen C (2018) Grading and frequency dependence of the resilient modulus of ballast. Géotech Lett 8(4):305-309

77. Claisse P, Calla C. Rail ballast: conclusions from a historical perspective. Published for the Institution of Civil Engineers by Thomas Telford Services, London

78. Pakalavan V, Nirvekala B, Kurukulasuriya LC (2016) Shear strength characteristics of different gradations of ballast using parallel gradation technique

79. Bian XC et al (2016) Critical particle size" and ballast gradation studied by discrete element modeling. Transp Geotech Supplement $C(1): 38-44$

80. Vizcarra GC, Nimbalkar S, Casagrande M (2016) Modeling behaviour of railway ballast in prismoidal apparatus using discrete element method. Procedia Eng 143:1177-1184

81. Marsal RJ (1973) Mechanical properties of rockfill. Wiley, Hoboken

82. Marsal RJ (1967) Large-scale testing of rockfill materials. J Soil Mech Found Div 93(2):27-43

83. Charles JA, Watts KS (1980) The influence of confining pressure on the shear strength of compacted rockfill. Geotechnique 30(4):353-367

84. Indraratna B et al (2006) Stabilization of ballasted rail tracks and underlying soft formation soils with geosynthetic grids and drains. In: Ground modification and seismic mitigation, pp 143-152

85. Feldman F, Nissen D (2002) Alternative testing method for the measurement of ballast fouling: percentage void contamination. In: CORE 2002: cost efficient railways through engineering, $\mathrm{p} 101$

86. Ionescu D (2004) Ballast degradation and measurement of ballast fouling

87. Indraratna B, Nimbalkar SS, Tennakoon N (2010) The behaviour of ballasted track foundations: track drainage and geosynthetic reinforcement. In: GeoFlorida 2010: advances in analysis, modeling \& design, pp 2378-2387
88. Qian Y et al (2018) Triaxial testing and discrete-element modelling of geogrid-stabilised rail ballast. Proc Inst Civ Eng Gr Improv 171(4):223-231

89. Norman G (1982) Ballast box experiments for evaluating ballast field performance. FRA report, pp 82-291

90. Gillian M (1983) Ballast performance evaluation with box tests. AREA 692:207-239

91. Lim WL (2004) Mechanics of railway ballast behaviour. University of Nottingham

92. Stewart HE, Selig ET, Norman-Gregory GM (1985) Failure criteria and lateral stresses in track foundations

93. Anderson WF, Key AJ (2000) Model testing of two-layer railway track ballast. J Geotech Geoenviron Eng 126(4):317-323

94. Indraratna B, Nimbalkar S (2013) Stress-strain degradation response of railway ballast stabilized with geosynthetics. J Geotech Geoenviron Eng 139(5):684-700

95. Indraratna B, Hussaini SKK, Vinod JS (2013) The lateral displacement response of geogrid-reinforced ballast under cyclic loading. Geotext Geomembr 39:20-29

96. Hussaini SKK, Indraratna B, Vinod JS (2016) A laboratory investigation to assess the functioning of railway ballast with and without geogrids. Transp Geotech 6:45-54

97. Chen $C$ et al (2015) Discrete element modelling of lateral displacement of a granular assembly under cyclic loading. Comput Geotech 69:474-484

98. Hussaini SKK, Indraratna B, Vinod JS (2015) Performance assessment of geogrid-reinforced railroad ballast during cyclic loading. Transp Geotech 2:99-107

99. Al-Saoudi NK, Hassan KH (2014) Behaviour of track ballast under repeated loading. Geotech Geol Eng 32(1):167-178

100. McDowell G, Stickley P (2006) Performance of geogrid-reinforced ballast. Ground Eng 39(1):26-30

101. Han X, Selig E (1996) Investigation of the effects of fouling material and degree of fouling on the settlement of ballast bed by ballast box. Project Report No. AAR95-426R for Association of American Railroads. University of Massachusetts, Amherst

102. Gerald P, Richard JB (1987) Performance of large-scale model single tie-ballast systems. Transp Res Rec 1134:7-14

103. Kwan CCJ (2006) Geogrid reinforcement of railway ballast. University of Nottingham

104. Indraratna B, lonescu D (2000) State of the art large scale testing of ballast

105. Alabbasi Y (2019) Discrete element modeling of railroad ballast under simulated train loading, College of Engineering-Civil \& Architectural Department, Qatar University, Doha, Qatar, p 209

106. Salim W (2004) Deformation and degradation aspects of ballast and constitutive modelling under cyclic loading

107. Sol-Sánchez M et al (2015) A study into the use of crumb rubber in railway ballast. Constr Build Mater 75:19-24

108. Du Plooy RF, Gräbe P (2017) Characterisation of rigid polyurethane foam-reinforced ballast through cyclic loading box tests. J S Afr Inst Civ Eng 59(2):2-10

109. Indraratna B, Biabani MM, Nimbalkar S (2015) Behavior of geocell-reinforced subballast subjected to cyclic loading in planestrain condition. J Geotech Geoenviron Eng 141(1):04014081

110. Ngo Ngoc T et al (2016) Experimental and discrete element modeling of geocell-stabilized subballast subjected to cyclic loading. J Geotech Geoenviron Eng 142(4):04015100

111. McDowell GR et al (2004) Comparison of ballast index tests for railway trackbeds. Proc Inst Civ Eng Geotech Eng 157(3):151-161

112. Navaratnarajah SK, Indraratna B, Ngo NT (2018) Influence of under sleeper pads on ballast behavior under cyclic loading: experimental and numerical studies. J Geotech Geoenviron Eng 144(9):04018068 
113. Esmaeili M, Aela P, Hosseini A (2017) Experimental assessment of cyclic behavior of sand-fouled ballast mixed with tire derived aggregates. Soil Dyn Earthq Eng 98:1-11

114. Panuccio C, Wayne R, Selig E (1978) Investigation of a plate index test for railroad ballast

115. Morgan J, Markland E (1981) The effect of vibration on ballast beds. Geotechnique 31(3):367-386

116. Chen C, McDowell GR, Thom N (2013) A study of geogridreinforced ballast using laboratory pull-out tests and discrete element modelling. Geomech Geoeng 8(4):244-253

117. Chen C, McDowell GR, Thom NH (2014) Investigating geogridreinforced ballast: experimental pull-out tests and discrete element modelling. Soils Found 54(1):1-11

118. Huang $\mathrm{H}$, Tutumluer E, Dombrow W (2009) Laboratory characterization of fouled railroad ballast behavior. Transp Res Rec J Transp Res Board 2117:93-101

119. Indraratna B, Ngo NT, Rujikiatkamjorn C (2011) Behavior of geogrid-reinforced ballast under various levels of fouling. Geotext Geomembr 29(3):313-322

120. Stark TD, Swan RH, Yuan Z (2014) Ballast direct shear testing. In: 2014 joint rail conference. American Society of Mechanical Engineers

121. Wang $Z$ et al (2015) Analysis of ballast direct shear tests by discrete element method under different normal stress. Meas J Int Meas Confed 63:17-24

122. Jin-Cai MZ, Chen-Xi T (2016) Shear strength of railway ballast. Electron J Geotech Eng 21:4759-4771

123. TolouKian AR, Sadeghi J, Zakeri J-A (2018) Large-scale direct shear tests on sand-contaminated ballast. Proc Inst Civ Eng Geotech Eng 171(5):451-461

124. Estaire J, Santana M (2018) Large direct shear tests performed with fresh ballast. In: Railroad ballast testing and properties. ASTM International
125. Biabani MM, Indraratna B (2015) An evaluation of the interface behaviour of rail subballast stabilised with geogrids and geomembranes. Geotext Geomembr 43(3):240-249

126. Esmaeili $M$ et al (2016) Experimental study on dynamic properties of railway ballast mixed with tire derived aggregate by modal shaker test. Adv Mech Eng 8(5):1687814016640245

127. Noålsund R, Tutumluer E, Horvli I (2013) Degradation of railway ballast through large scale triaxial and full scale rail track model tests: comparison with mechanical laboratory tests. In: Proceedings of 10th international conference on bearing capacity of roads, railways and airfields

128. Li W et al (2018) Full-scale model testing on ballasted highspeed railway: dynamic responses and accumulated settlements. Transp Res Rec 2672(10):125-135

129. Liu S et al (2017) Comparison of laboratory testing using smartrock and discrete element modeling of ballast particle movement. J Mater Civ Eng 29(3):D6016001

130. Al Shaer A et al (2008) Experimental settlement and dynamic behavior of a portion of ballasted railway track under high speed trains. J Sound Vib 316(1-5):211-233

131. Koike $Y$ et al (2014) Numerical method for evaluating the lateral resistance of sleepers in ballasted tracks. Soils Found 54(3):502-514

132. Kumara JJ, Hayano K (2016) Deformation characteristics of fresh and fouled ballasts subjected to tamping maintenance. Soils Found 56(4):652-663

133. Janoo V (1998) Quantification of shape, angularity, and surface texture of base course materials. Cold Regions Research and Engineering Lab, Hanover, $\mathrm{NH}$

Publisher's Note Springer Nature remains neutral with regard to jurisdictional claims in published maps and institutional affiliations. 